\title{
An Overview of Analytical Determination of Diltiazem, Cimetidine, Ranitidine, and Famotidine by UV Spectrophotometry and HPLC Technique
}

\author{
Nighat Shafi, ${ }_{1}^{1}$ Farhan Ahmed Siddiqui, ${ }^{1}$ Huma Naseem, ${ }^{2}$ Nawab Sher, ${ }^{3}$ Arif Zubair, \\ Azhar Hussain, ${ }^{5}$ Ali Akbar Sial, 1 and Mirza Tasawer Baig ${ }^{1}$ \\ ${ }^{1}$ Faculty of Pharmacy, Federal Urdu University Arts Science and Technology, Karachi 75300, Pakistan \\ ${ }^{2}$ Department of Pharmaceutical Chemistry, Faculty of Pharmacy, University of Karachi, Karachi 75270, Pakistan \\ ${ }^{3}$ Department of Chemistry, University of Karachi, Karachi 75270, Pakistan \\ ${ }^{4}$ Department of Environmental Sciences, Faculty of Science, Federal Urdu University Arts Science and Technology, \\ Karachi 75300, Pakistan \\ ${ }^{5}$ Department of Pharmaceutics, Faculty of Pharmacy, University of Karachi, Karachi 75270, Pakistan
}

Correspondence should be addressed to Farhan Ahmed Siddiqui; farhanchemist@gmail.com

Received 5 May 2013; Revised 8 July 2013; Accepted 9 July 2013

Academic Editor: Ghada M. Hadad

Copyright (C) 2013 Nighat Shafi et al. This is an open access article distributed under the Creative Commons Attribution License, which permits unrestricted use, distribution, and reproduction in any medium, provided the original work is properly cited.

\begin{abstract}
This review article recapitulates the analytical methods for the quantitative determinations of diltiazem and three $\mathrm{H}_{2}$ receptor antagonists (cimetidine, ranitidine, and famotidine) by one of the spectroscopic technique (UV spectrophotometery) and separation technique such as high-performance liquid chromatography (HPLC). The clinical and pharmaceutical analysis of these drugs requires effective analytical procedures for quality control, pharmaceutical dosage formulations, and biological fluids. An extensive survey of the literature published in various analytical and pharmaceutical chemistry-related journals has been compiled in its review. A synopsis of reported spectrophotometric and high-performance liquid chromatographic methods for individual drug is integrated. This appraisal illustrates that majority of the HPLC methods reviewed are based on the quantitative analysis of drugs in biological fluids, and they are appropriate for therapeutic drug monitoring purpose.
\end{abstract}

\section{Introduction}

1.1. Diltiazem Hydrochloride. Diltiazem hydrochloride (DLZ), d-cis diltiazem, d-cis-3-acetyloxy-5-[2-(dimethylamino) ethyl]-2,3-dihydro-2-(4-methoxyphenyl)-1,5-benzothiazepin- $4(5 \mathrm{H})$ one)hydrochloride (Figure 1 ) are one of the widely used benzothiazepine $\mathrm{Ca}^{2+}$-blocking drugs (calcium channel blockers). Clinically it is used to treat cardiovascular diseases such as angina pectoris, hypertension, and cardiac arrhythmias $[1,2]$.

1.2. Histamine $\mathrm{H}_{2}$ Receptor Antagonists. Histamine $\mathrm{H}_{2}$ receptor antagonists: cimetidine (CIM), ranitidine (RAN), and famotidine (FAM) classified as class III drugs (high solubility, low permeability) according to the Biopharmaceutics Classification System (BCS) [3, 4] are used in the treatment of gastrooesophageal reflux disease and gastric and duodenal ulceration [5].

1.3. Cimetidine. Cimetidine is N-Cyano-N-methyl-N-[2[[(5-methyl-1H-imidazol-4-yl)methyl]thio]ethyl]guanidine, contains imidazole ring (Figure 2), and inhibits hepatic cytochrome P450 (CYP) 1A2, 2C9, 2D6, and 3A4 P450 isoforms [6].

1.4. Ranitidine Hydrochloride. Ranitidine hydrochloride is $N$-\{2-[[[5-[(dimethylamino)methyl]-2 furanyl]methyl]thio] ethyl\}- $N^{\prime}$-methyl-2-nitro-1,1-ethenediamine (Figure 3), a histamine $\mathrm{H}_{2}$ receptor antagonist with a furan ring structure that increases its potency to inhibit gastric acid secretion induced by various stimuli, while lacking the antiandrogenic and hepatic microsomal enzyme-inhibiting effects [7]. 


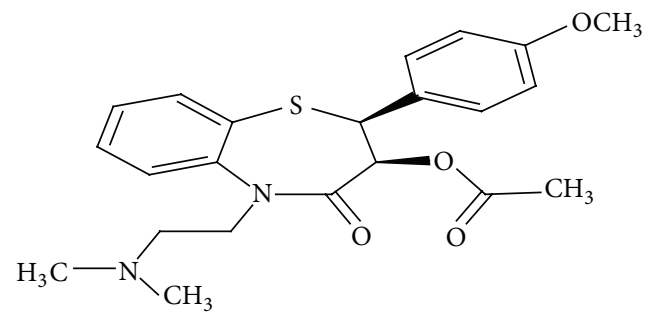

FIGURE 1: Diltiazem.

1.5. Famotidine. Famotidine, 3-[[[2-[(aminoiminomethyl) amino]-4-thiazolyl $]$ methyl]thio]- $N$ (aminosulfonyl) (Figure 4 ), is highly selective histamine $\mathrm{H}_{2}$ receptor antagonist, indicated for the treatment of duodenal ulcer, gastric ulcer, gastroesophageal reflux disease, and Zollinger-Ellison syndrome [8], in the treatment of Parkinson's and inhibits basal and nocturnal gastric secretion as well as secretion stimulated by food and pentagastrin [9].

The present review article deals with the analytical methods that are useful for pure form, pharmaceutical formulations, and biological specimens of diltiazem and $\mathrm{H}_{2}$ receptor antagonists (cimetidine, ranitidine, and famotidine) were focused and summarized.

\section{Analytical Methods}

Assay method development is very significant for pharmaceutical industries and pathological laboratories, and this is always desirable to select and develop simple, accurate, precise, and economical method for the determination of drugs in pharmaceutical dosage forms and pathological samples. Analytical data are used to screen potential drugs in biological samples, aid in the development of drug syntheses, support formulation studies, monitor the stability of bulk pharmaceuticals and formulated products, and test final products for release [10].

\section{Official and Compendial Methods of Analysis}

Monographs in the "Analytical Profile of Drug Substances" series were also published for diltiazem [11], cimetidine [12], and ranitidine [13]. Eur Ph 2002 [14] recommends an HPLC assay for diltiazem in its dosage forms. Stability-indicating method for the determination of diltiazem hydrochloride in formulated oral preparations by the HPLC technique has been recommended in USP 29 [15]. High-performance liquid chromatographic methods are prescribed according to B.P 2011 and USP 34 for quantitative analysis of pharmaceuticals containing cimetidine, ranitidine hydrochloride, and famotidine [16-20]. Chromatographic conditions of official methods are presented in Table 1. However, British Pharmacopeia [21] recommended potentiometric titration method with $0.1 \mathrm{M} \mathrm{NaOH}$ for ranitidine hydrochloride.

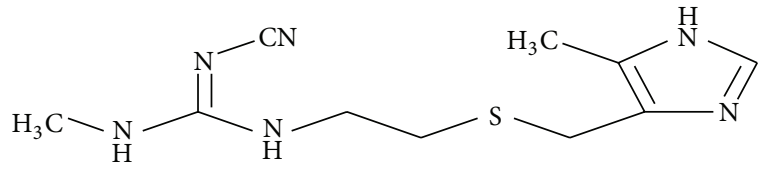

Figure 2: Cimetidine.

\section{Reported Methods of Analysis}

4.1. Diltiazem. Literature survey revealed that a number of assay methods have been used for analysis of diltiazem in bulk drug, pharmaceutical preparations, and serum using different techniques including LC-MS/MS [22-24], gas chromatography [25-28], and electron capture gas chromatography [29].

4.1.1. Spectrophotometric Methods. Many research papers have described the spectrophotometric methods for the detection of diltiazem in raw materials and different pharmaceutical formulations. Recently Ayad et al. [30] established a method by kinetic spectrophotometric and spectrofluorimetric technique using NBD-Cl (4-Chloro-7-nitrobenzene-2oxa-1,3-diazole). The reported method has many advantages in contrast with other methods in terms of sensitivity and selectivity by way of high-quality precision and accuracy. Hosny [31] reported an ion-pair complex formation method for the assaying of diltiazem in its formulation by using chromotrope $2 \mathrm{R}$ and rose bengal reagents. Another spectrophotometric determination of diltiazem by ternary complex formation reaction with cobalt thiocyanate at acidic $\mathrm{pH}$ (35). After extraction complex was deliberated at $627 \mathrm{~nm}$ [32]. Pietraś et al. [33] compare the classical and derivative spectrophotometric method for the quantitations of diltiazem in bulk and formulation. Assay was performed by the firstand second-order method with the application of "peakzero" and "peak-peak" techniques with excellent correlation coefficient $\left(r^{2}<0.9999\right)$. Sabino et al. [34] presented a very sensitive determination of diltiazem by the reduction of $\mathrm{Cu}$ (II) in buffer ( $\mathrm{pH} 7$ ) and micellar medium be full of 4,4dicarboxy-2,2 biquinoline acid. $\mathrm{Cu}(\mathrm{I})$ produced as a result of reduction of $\mathrm{Cu}$ (II) reacts with 4,4-dicarboxy-2,2 biquinoline acid-formed complexes which was quantitatively detected at $558 \mathrm{~nm}$. Similarly, chloro drug derivative of diltiazem was formed by means of reaction involving tertiary amino group of diltiazem and sodium hypochlorite. Newly formed derivative then reacted with starch and potassium iodide in sodium bicarbonate solution given blue color complex quantitatively read out at $540 \mathrm{~nm}$ [35]. Leitãoa and Esteves da Silva reported a spectrophotometric method based on kinetic study by factorial analysis. Drug was reacted in two stages with hydroxylamine and a ferric salt; as a result, hydroxamic acid and ferric hydroxamate were formed, respectively [36]. Diltiazem was quantitatively investigated in capsule and tablet dosage form by means of reaction with sodium metavanadate in acidic medium (sulfuric acid) and spectrophotometrically measured at $750 \mathrm{~nm}$ [37]. Ayad et al., [38] describe an analytical method by means of oxidation reaction of diltiazem with iron(III) in acidic environment while 
TABLE 1: Official methods of analysis.

\begin{tabular}{|c|c|c|c|c|}
\hline Drug & Column & Mobile phase & $\mathrm{nm}$ & Ref. \\
\hline Diltiazem & Column L1 $4.6 \times 300 \mathrm{~mm}$ & Buffer : MeOH : ACN $(50: 25: 25)$. & 240 & $\begin{array}{l}{[15]} \\
\text { USP }\end{array}$ \\
\hline \multirow[t]{2}{*}{ Cimetidine } & Column L1 $4.6 \times 250 \mathrm{~mm}$ & $\begin{array}{l}\mathrm{MeOH}: \mathrm{H}_{3} \mathrm{PO}_{4}:(\mathrm{Sod}, \mathrm{Hex} \text { sulphonate })(240 \mathrm{~mL}: 0.3 \mathrm{~mL}: 940 \mathrm{mg}) \\
\text { make up to } 1 \mathrm{~L}\end{array}$ & 220 & $\begin{array}{l}\text { USP } \\
{[16]}\end{array}$ \\
\hline & Column C18 4.6×250 mm & $\begin{array}{l}\text { Buffer }(1.1 \mathrm{~g} \text { Sod, Hex sulphonate in } 780 \mathrm{~mL} \text { water }+0.4 \mathrm{~mL} \text { diethyl } \\
\left.\text { amine, } \mathrm{pH} 2.8 \text { by } \mathrm{H}_{3} \mathrm{PO}_{4}\right)+250 \mathrm{~mL} \mathrm{MeOH}\end{array}$ & 220 & $\begin{array}{l}\text { B.P } \\
{[17]}\end{array}$ \\
\hline Ranitidine & Column L1 $4.6 \times 200 \mathrm{~mm}$ & $\begin{array}{l}\mathrm{MeOH}: \text { buffer }(85: 15) \\
\text { buffer: } 0.1 \mathrm{M} \text { ammonium cyanate }\end{array}$ & 322 & $\begin{array}{l}\text { USP } \\
{[18]}\end{array}$ \\
\hline \multirow[t]{2}{*}{ Famotidine } & Column L1 $4.6 \times 250 \mathrm{~mm}$ & Water : $\mathrm{MeOH}$ : buffer $(32: 5: 3)$, buffer: $13.8 \mathrm{~g} \mathrm{NaH}_{2} \mathrm{PO}_{4}$ in water-1L & 254 & $\begin{array}{l}\text { USP } \\
{[19]}\end{array}$ \\
\hline & $\begin{array}{l}\text { Column } \mathrm{C} 184.6 \times 250 \mathrm{~mm} \text {, } \\
\text { temp: } 50^{\circ} \mathrm{C}\end{array}$ & $\begin{array}{l}\mathrm{MeOH}: \mathrm{ACN}: \text { buffer }(6: 94: 900) \text {, buffer ( } 1.88 \mathrm{~g} \text { Sod, Hex sulphonate) } \\
\text { in } 900 \mathrm{~mL} \text { water-ph } 3.5 \text { by acetic acid }\end{array}$ & 265 & $\begin{array}{l}\text { B.P } \\
{[20]}\end{array}$ \\
\hline
\end{tabular}<smiles>CN/C(=C\[N+](=O)[O-])NCCSCc1ccc(CN(C)C)o1</smiles>

Figure 3: Ranitidine.<smiles>NC(N)=Nc1nc(CSCC/C(N)=N/S(N)(=O)=O)cs1</smiles>

Figure 4: Famotidine.

iron(III) is converted into iron(II) which reacted with the 1,10-phenanthroline or 2,2-bipyridyl in the direction of stable complexes deliberated at 510 and $520 \mathrm{~nm}$, respectively. In the same way, another oxidation-reduction reaction of diltiazem was established by the El-Didamony with $N$-bromosuccinimide (NBS). Remaining NBS was then measured by the decline in absorbance of amaranth dye or by ceric ammonium sulfate whereas, remaining oxidant was deliberated by diminish in the shade of chromotrope $2 \mathrm{R}$ or rhodamine 6G [39].

A simple and reproducible method based on the formation of hydroxamic acid which reacts with iron(III) forming a complex with a maximum absorption at $525 \mathrm{~nm}$ [40], coloured complex of the drug with cobalt thiocyanate and methyl orange [41], showed linearity in the range 60-600 and 5-60 $\mu \mathrm{g} \mathrm{mL}^{-1}$ with the absorption maxima at 630 and $420 \mathrm{~nm}$, respectively. Indirect determination of diltiazem in pure form and pharmaceutical formulations presented by Kamath and Shivram [42]. Kamath also developed a selective method using the ferric hydroxamate method and detected at $500 \mathrm{~nm}$ in the range of $50-800 \mu \mathrm{g} \mathrm{mL}^{-1}$ [43]. Spectrophotometric method in pharmaceuticals was based on the reaction of hydrolyzed diltiazem with folin-Ciocalteu reagent and measurement of the coloured compound at $750 \mathrm{~nm}$ [44]. Formulations of diltiazem were also determined by extractive spectrophotometric methods using bromothymol blue, bromophenol blue, and bromocresol green [45]. Abu-Shadi et al. [46] established two accurate and selective methods that comprise the reaction of 2,3 dichloro-5,6-dicyanoquinone DDQ with dipyridamole, celiprolol, and diltiazem to develop highly coloured radical anions. In the second method, Fe(III) hydroxamate reacts with diltiazem to produce red complexes. In vitro dissolution study was performed for 240 minutes and measured spectrophotometrically at $240 \mathrm{~nm}$. Parameters of mean dissolution time and time for $70 \%$ dissolution $\left(T_{70}\right)$ were also determined [47].

4.1.2. HPLC Methods. At present, HPLC is the most widely used technique for the analysis of bulk drugs and their formulations [48]. Derivatization of the drugs prior to analysis is normally not required. The sample preparation is extremely simple and the errors associated with it are generally kept to a minimum by using HPLC [49]. Several examinations using HPLC for determination of diltiazem (Table 2) in bulk drug substances and their formulations have been reported. Indian authors, Cumar et al., [50] documented an analytical method as per ICH guidelines for bulk and tablet dosage form on Zorbax-SB Phenyl column by using UV detector. Linearity was performed on $50-150 \mu \mathrm{g} \mathrm{mL}^{-1}$ range while, correlation of coefficient was fitted at 0.9987 . Sultana et al. [51] provides a well-organized and reproducible separation of the components with UV detection. A reliable and simple method was presented with a binary solvent system. Standardized extraction procedures for drugs in various dosage forms were 
TABLE 2: Application of HPLC to the determination of diltiazem.

\begin{tabular}{|c|c|c|c|}
\hline Column & Mobile phase & $\mathrm{nm}$ & Ref. \\
\hline $50 \times 4.6 \mathrm{~mm} ; 1.8 \mu \mathrm{m}$; Zorbax SB-Phenyl & $\begin{array}{l}\mathrm{ACN}: \text { water }(60: 40)+1 \mathrm{Ml} \\
\text { Trifluoroacetic acid }\end{array}$ & 238 & {$[50]$} \\
\hline Hypersil, ODS, C-18 $(150 \times 4.6 \mathrm{~mm}, 5$ micron $)$ & Methanol: water $(80: 20 \mathrm{v} / \mathrm{v}, \mathrm{pH} 3.1)$ & 236 & {$[51]$} \\
\hline $\mathrm{C}_{18}$ Bondapak RP column & $\mathrm{MeCN}$ and $0.05 \mathrm{M} \mathrm{KH}_{2} \mathrm{PO}_{4}$ & 237 & {$[52]$} \\
\hline Spherisorb $\mathrm{S}_{5} \mathrm{~W}$ & $\mathrm{MeOH}-\mathrm{CH}_{2} \mathrm{Cl}_{2}$-hexane & 237 & {$[58]$} \\
\hline Short alkyl chain, silanol-deactivated column & Methanol : buffer $(50: 50)$ & 237 & [59] \\
\hline $\mathrm{C}_{18}$-bonded silica gel & Methanol: phosphate buffer-diethyl amine & 237 & {$[60]$} \\
\hline Stainless steel, Bondapak- $\mathrm{C}_{18} 10 \mathrm{~m}$ column & Methanol: TEMED (0.8\%, pH 5.4), $60: 40$ (vol/vol) & 238 & {$[61]$} \\
\hline Spherisorb $\mathrm{C}_{18}$ column & Methanol-water triethylamine & 239 & {$[67]$} \\
\hline $\begin{array}{l}\mathrm{C}_{18} \text {-reversed phase column, Bondapak, } 10 \mathrm{~m} \text { silica, } 300 \\
(3.9 \mathrm{~mm} \text { I.D.) }\end{array}$ & $\begin{array}{l}\text { Methanol-acetonitrile-0.04 } \mathrm{M} \text { ammonium } \\
\text { Bromide-triethyl ammine }(40: 24: 36: 0.06), \mathrm{pH}<6.4\end{array}$ & 237 & {$[68]$} \\
\hline $5 \mu \mathrm{m}$ Lichrocart Lichrospher 60 RP-select B & Acetonitrile $0.025 \mathrm{molL}^{-1} \mathrm{KH}_{2} \mathrm{PO}_{4} 35: 64(\mathrm{v} / \mathrm{v}), 5.5 \mathrm{pH}$ & 215 & {$[74]$} \\
\hline $\begin{array}{l}\text { A } 15 \mathrm{~cm} \times 4.1 \mathrm{~mm} \text {, pH-stable }(\mathrm{pH} 1-13) \text { polymeric reverse } \\
\text { phase column }\end{array}$ & $\begin{array}{l}\text { MeCN-0.01 M tetrabutyl-ammonium hydroxide }(60: 40 \text {, } \\
\mathrm{v} / \mathrm{v})\end{array}$ & 254 & {$[75]$} \\
\hline Hiber, 250-4.6 RP-18 column & $\mathrm{ACN}:$ water $(85: 15 \mathrm{v} / \mathrm{v}, \mathrm{pH} 2.6 \pm 0.02)$ & 230 & {$[80]$} \\
\hline $\begin{array}{l}\text { Kromasil C18 column }(300 \mathrm{~mm} \times 4 \mathrm{~mm} \text { i.d., } 10 \mu \mathrm{m} \text { particle } \\
\text { size) }\end{array}$ & Methanol : water $(90: 10 \mathrm{v} / \mathrm{v})$ & 237 & {$[81]$} \\
\hline Hiber, 250-4.6 RP-18 column & ACN : methanol : water $(30: 20: 50, \mathrm{v} / \mathrm{v}, \mathrm{pH} 2.59 \pm 0.02)$ & 230 & [82] \\
\hline Hiber RT 250-4.6 Purospher Star RP-18 column & Methanol : water, $80: 20$ (v/v, pH $3.1 \pm 0.02)$ & 240 & {$[83]$} \\
\hline Hiber, RP-18 column & ACN : methanol: water $(30: 20: 50 \mathrm{v} / \mathrm{v}, \mathrm{pH} 3.6)$ & 230 & {$[84]$} \\
\hline Nuclosil 100-10 C-18 $(250 \times 4.6 \mathrm{~mm})$ & ACN : methanol : water $(10: 55: 35 \mathrm{v} / \mathrm{v}, \mathrm{pH} 2.65 \pm 0.02)$ & 240 & {$[85]$} \\
\hline Purospher STAR RP-18 end capped ( $5 \mu \mathrm{m})$ & Methanol : water $(60: 40 \mathrm{v} / \mathrm{v})$ with $\mathrm{pH} 3.9$ & 230 & {$[86]$} \\
\hline Spherisorb $\mathrm{S}_{5} \mathrm{~W}$ silica column & $10 \mathrm{mM}$ ammonium perchlorate in $\mathrm{MeOH} \mathrm{pH} 7.6$ & 240 & {$[97]$} \\
\hline Radial-PAK CN column & $0.06 \mathrm{M} \mathrm{KH}_{2} \mathrm{PO}_{4}-\mathrm{MeOH}-\mathrm{Et}_{3} \mathrm{~N}(55: 45: 0: 25)$ & 237 & {$[98]$} \\
\hline Nucleosil C-18 column & Acetonitrile- $0.1 \mathrm{M} \mathrm{NH}_{4} \mathrm{H}_{2} \mathrm{PO}_{4}(37: 63)$ & 237 & {$[100]$} \\
\hline Cyanopropylsilane, RP column & Acetonitrile-phosphate buffer triethylamine ( $\mathrm{pH} 3.5)$ & 237 & {$[101]$} \\
\hline Supelcosil LC-8-DB column & MeOH-0.05 M phosphate buffer pH $5.0(1: 1)$ & 237 & [102] \\
\hline$\mu$-Bondapak CN RP column & $\begin{array}{l}0.01 \mathrm{M} \text { Na phosphate buffer ( } \mathrm{pH} 5.0)-\mathrm{MeOH} \text {-diethylamine } \\
(55: 45: 0.5)\end{array}$ & 254 & [109] \\
\hline
\end{tabular}

also developed and successfully applied to a wide range of current pharmaceutical formulations [52]. Trans-Diltiazem, 7 known, and several unknown related compounds were separated from diltiazem-HCl. Minimum detectable amount and the relative standard deviation of the assay procedure were 0.1 and $0.15 \%$, respectively [53].

4.1.3. Bioanalytical Methods by HPLC. Several investigations performed [54-56] on development of HPLC methods for determination of drugs in biological fluids. Li et al. [57] presented an HPLC method and applied in pharmacokinetic studies. Drug was extracted in mixture of hexane, chloroform, and isopropanol $(60: 40: 5 \mathrm{v} / \mathrm{v} / \mathrm{v})$ and separated with isocratic mode. Method was linear over the clinical range of 0-300 $\mathrm{ng} \mathrm{mL}^{-1}$ with $3 \mathrm{ng} \mathrm{mL}^{-1}$ of LOD. Spiked extraction recoveries of diltiazem were found to be $91.4-104.0 \%$.

Kinney and Kelly reported [58] an estimation of diltiazem in plasma using normal-phase column liquid chromatography with ultraviolet detection. Chaudhary et al. [59] developed a liquid chromatographic method in human serum involving one-step deproteinization of serum by using acetonitrile. A sensitive method was developed by using an end-capped reversed-phase column with a regression coefficient of 0.9998 [60]. Several writers have carried out the determination of diltiazem in biological samples after liquidliquid extraction by means of ethyl acetate [61], methyl tertbutyl ether [62-66], a mixture of $n$-hexane-methylethanoldichloromethane-mmonia [67], and hexane and isopropanol [68]. A few of these schemes engage extraction of diltiazem with organic solvents and back-extraction into phosphoric acid [64], hydrochloric acid [61, 63, 65], and sulfuric acid $[62,68]$. However, these attempts are reported to be adequately sensitive, the drug has been deliberated using either a large plasma sample volume or the suggested extraction procedures give rise to poor separation of the investigated drug from endogenous interferences in biological specimens, and recovery of about $80-85 \%$. Ascalone and Dal Bo [69] and Mangani et al. [70] have projected an automated HPLC estimation of diltiazem in human plasma by means of a column-switching technique for online cleanup. These investigations have a very low limit of detection while some drawbacks are their high reagent consumption and the need of two pumps. Hubert et al. [71] described an automated method for the quantitation of diltiazem in human plasma 
via liquid-solid extraction on a disposable cartridge coupled to HPLC. Christensen et al. [72] and Ascalone et al. [73] have executed the partition of diltiazem from plasma with solidphase extraction on C18 cartridges; however, this type of cartridge gave relatively low recovery values $(75-80 \%)$. These investigations overcome problems caused by endogenous compounds. Zendelovska et al. [74] propose a new method in plasma samples using solid-phase extraction on RP-select B cartridges and liquid-liquid extraction with diethyl ether. The rewards of these methods are low reagent consumption, short analysis time, ease of operation, no matrix interferences, and satisfactory limit of quantification to enable pharmacokinetic studies of diltiazem. Rustum [75] utilized a salting-out extraction procedure and polymeric reversed-phase column for the determination of diltiazem in human whole blood.

HPLC analysis of diltiazem in plasma for pharmacokinetic study in a healthy man also has been reported [76]. Pharmacokinetic parameters of diltiazem were determined using a sensitive and reproducible HPLC method which followed international standards in validation of the analytical assay [77]. Another method consists of extraction of the drugs by using hexane-isopropanol $(98: 2)$ followed by solvent evaporation and redissolution of the residue in $\mathrm{MeCN}-0.5 \mathrm{M}$ $\mathrm{KH}_{2} \mathrm{PO}_{4}$ (pH 2.5, 30:70) [78]. Synchronized detection of diltiazem and six of its metabolites is known to occur in humans. The assay was successfully applied to detect the kinetics of these drugs in healthy volunteers [79].

4.1.4. Simultaneous Determination. Diltiazem was also simultaneously determined by HPLC technique in bulk, dosage form and successfully applied in human serum with other classes of drugs due to their coadministration. Prior to determination method was optimized and validated according to respective ICH guidelines. For the first time in the literature diltizem and statins (simvastatin, rosuvastatin and atorvastatin) were separated on isocratic eluation by RP-HPLC with UV detection. Method was optimized with different ratios of mobile phase, C18 columns, organic modifier, and $\mathrm{pH}$ of mobile phase. Method was found to be linear $\left(0.625-20 \mathrm{mg} \mathrm{mL}^{-1}\right)$, accurate (97.9-102\%), precise $(\mathrm{CV}<2 \%)$, and also robust with short time of analysis $(<10 \mathrm{~min})$ [80]. In the same way, diltiazem and lovastatin were simultaneously estimated by Kulkarni et al. [81] and, for the first the time, reported in writing style. Both the drugs were separated on Kromasil C18 column with UV detector in the presence of propranolol as an internal standard. Simultaneous determination of diltiazem and three hypoglycaemic drugs, type II (non-insulin-dependent) diabetes mellitus are reported in 2011. Method was optimized and validated isocratically mode and no significant meddlings were found from tablet excipients. Intraday (0.56 to $1.31 \%$ ) and interday (0.56 to $1.39 \%)$ precision and accuracy/recovery (98-102\%) were within limits. All the analytes were eluated within $6 \mathrm{~min}$ which is important for quality control analysis) [82]. RPHPLC method of diltiazem with four commonly prescribed non steroidal anti-inflammatory drugs (NSAIDs) is also documented by Sultana et al., in accordance with the ICH guidelines. Separation was achieved on C18 column at ambient temperature. Method was linear in the desired range $1.25-50 \mu \mathrm{g} \mathrm{mL}^{-1}$ with the best resolution and recovery in serum (98.97-100.4\%) [83]. Another simple, reproducible, and economically cost-effective HPLC method for quantitative determination diltiazem and quinolones is reported by Sultana et al., in 2009. Diltiazem and quinolones were efficiently separated on Hiber, 250-4.6 STAR RP-18 column in the presence of internal standard. The developed method was verified by later in vitro interaction studies of diltiazem with fluoroquinolones [84]. Shabana et al. describe a simple RP-HPLC method for simultaneous separation of diltiazem, prazosin hydrochloride, and two other calcium channel blockers on 10-micron particle size column. The developed method has advantages over other reported methods due to their short time of analysis (within 7 minutes) and for their sensitivity; that is, LOD and LOQ were achieved at 0.0542 and $0.1642 \mu \mathrm{g} \mathrm{m}^{-1}$, respectively [85]. Diltiazem, cimetidine, ranitidine, and famotidine were simultaneously separated on Purospher STAR RP-18 end capped $(5 \mu \mathrm{m})$ with isocratic eluation. Calibration curves were linear within the range of $2-12 \mu \mathrm{g} \mathrm{mL}^{-1}$ with excellent correlation coefficients $\leq 0.999$. The developed method was competent with high precision $(\leq 1.9 \%)$ and accuracy (96.1-102.5\%) and successfully applied for the in vitro interaction studies of diltiazem and $\mathrm{H}_{2}$ antagonists [86]. However, several analytical procedures have also been described for simultaneous separation and enantioseparation of diltiazem, its analogs, possible degradation products, and metabolites. Simultaneous identification and quantification of six commonly prescribed calcium channel blocking drugs by single-step extraction method was established by Jianchun from alkaline samples [87]. The HPLC modes show adequate sensitivity and reproducibility to cover the concentration range $10-400 \mathrm{ng} \mathrm{mL}^{-1}$ required as therapeutic levels in plasma for these drugs [88]. Li et al. [89] developed a common method for the detection of diltiazem, verapamil, nifedipine, nitrendipine, and their active metabolites using a $\mathrm{C} 18$ column. The detection limit of the assay was $8 \mathrm{ng} \mathrm{mL}^{-1}$ for all compounds over the concentration range 1-1000 $\mathrm{ng} \mathrm{mL}^{-1}$. The optical isomers of dL-cisdiltiazem were detected by hydrolysis of and esterification with the chiral reagent d-2-(2-naphthyl) propionyl chloride. RP HPLC separation was achieved with $0.01 \mathrm{M} \mathrm{NH}_{4} \mathrm{OAC}$ MeCN (1:9), pH 6.6, and detection was performed at $254 \mathrm{~nm}$ [90]. Direct enantiomeric seperation of cis- $( \pm)$ diltiazem in plasma was achieved on ovomucoid [91] and topical $2 \%$ diltiazem formulations [92] column. The former involves a deproteinization of serum and acetonitrile used for sample cleanup. The degree of extraction of the enantiomers was $86 \%$ in the later method. Packed column subcritical and supercritical fluid chromatography ( $\mathrm{p}$-sub or pSFC) has been used as a powerful chiral separation technique, for the resolution of optical isomers of diltiazem. P-sub- or p-SFC tends to obtain higher column efficiency than normal-phase HPLC [93]. Direct resolution of four optical isomers was completely resolved on both normal- and reversed-phase chiralcel of columns. This chiral resolution was applied to determine 3 optical impurities that might be present in diltiazem and its tablets [94]. The enantiomers separations, 
the 8-chloro derivative of diltiazem (clentiazem maleate) and their deacetyl forms were resolved on ovomucoidbonded chiral stationary phase with a mobile phase of acetonitrile-0.02 M phosphate buffer ( $\mathrm{pH}$ 6.0) [95]. S(-)N-1-(2naphthylsulfonyl)-2-pyrrolidinecarbonyl chloride (a highly optically pure derivatization reagent) was developed for converting enantiomers into diastereomers for subsequent resolution by high-performance liquid chromatography [96]. HPLC measurements of diltiazem and its metabolites were also investigated in biological fluids [97-104]. Diltiazem was detected in the presence of desacetyldiltiazem on Lichrosorb RP 18 column with acetate-MeCN-MeOH $(50: 40: 10)$ and also purified by preparative HPLC on LiChroprep Si60 with petroleum ether-EtOAc-MeOH $(50: 50: 5)$ as mobile phase [105]. Simultaneous analysis of diltiazem, N-monodemethyldiltiazem, and desactyldiltiazem were identified with the extraction efficiency of $95-100 \%$ and the limit of detection was $5 \mathrm{ng} \mathrm{mL}^{-1}$ [106]. Different C18 columns are compared with the influences of organic cosolvent, $\mathrm{pH}$, ionic strength and the addition of various amines for the detection of diltiazem and its 5 metabolites [107]. Goebel and Koelle described a very sensitive method for the determination of diltiazem and four of its metabolites in plasma samples. Calibration curves were linear between 1 and $800 \mathrm{ng} \mathrm{mL}^{-1}$ and the lower limit of detection was $0.1-0.2 \mathrm{ng} \mathrm{mL}^{-1}$ [108]. HPLC combined with mass spectrometry was used for the analysis of diltiazem and its 3 metabolites in blood plasma of patients treated for ischemic heart disease [109]. A sensitive and automatic method for the analysis of diltiazem and its main metabolites in acidified serum is described using solidliquid extraction on disposable extraction cartridges. This method avoids the in vitro degradation and eliminates the numerous manipulations involved in liquid-liquid extraction [110]. Tracqui et al. [111] developed an automated method by using liquid-solid extraction on disposable extraction cartridges in combination with HPLC. Lee et al. established [112] a method that involves the use of two $5 \mu \mathrm{m}$ BDS silica gel columns $15 \mathrm{~cm}$ ( $4.6 \mathrm{~mm}$ I.D) in series for increased resolution and sensitivity and organic mobile phase for both extraction and elution of diltiazem. Dasandi and his coworkers [113] have described a high-throughput and specific method using ultraperformance liquid chromatography tandem mass spectrometry (UPLC-MS/MS). Compared with the published methods, the narrow peaks produced by UPLC are of particular advantage when coupled to electrospray mass spectrometry and offering superior sensitivity. Total run time was $2.0 \mathrm{~min}$ only; therefore, the method is particularly suitable for routine assay. Zoest and his companions [114] developed a sensitive, specific, and reproducible assay for the pharmacokinetic study of diltiazem, primary and secondary metabolites of diltiazem.

\subsection{Cimetidine}

4.2.1. Spectrophotometric Methods. Sensitive spectrophotometric method based on the reaction of CIM, RAN, FAM, and NIZ with $N$-bromosuccinimide (NBS) and subsequent measurement of the excess NBS by its reaction with $p$ aminophenol to give a violet-colored product. Decrease in the absorption intensity $(\Delta A)$ of the colored product, due to the presence of the drug, was correlated with its concentration in the sample solution $\left(\lambda_{\max }\right.$ at $\left.552 \mathrm{~nm}\right)$ [115]. Another sensitive method presented by Darwish et al., [116] for determination of $\mathrm{H}_{2}$ receptor antagonists based on the oxidation of these drugs with cerium(IV) in presence of perchloric acid and subsequent measurement of the excess Ce(IV) by its reaction with p-dimethylaminobenzaldehyde to give a redcolored product $\left(\lambda_{\max }\right.$ at $\left.464 \mathrm{~nm}\right)$. Fast spectrophotometric methods for the analysis of CIM in pharmaceuticals and human urine using batch and flow-injection procedures based on the formation of a green complex drug and $\mathrm{Cu}(\mathrm{II})$ in acetic/acetate medium, measured at $330 \mathrm{~nm}$ [117]. Two fast methods developed by Garcia et al. [118] using batch and flow-injection procedures for CIM based on the formation of a green complex with $\mathrm{Cu}(\mathrm{II})$ in acetic/acetate medium, measured at $330 \mathrm{~nm}$. Kelani et al. [119] described three sensitive stability indicating spectrophotometric methods using sodium nitro prusside, 3-methyl-2-benzo-thiazolinone hydrazine, and cobalt(II), respectively.

4.2.2. HPLC Methods. CIM is highly polar drug; therefore, several RP-HPLC methods reported on the analysis in pure form, tablet and biological fluids (Table 3) using either a $\mathrm{C}_{8}$ [120], C18 [121-127], or polymeric column [128]. Determination of CIM in human plasma and urine samples has been investigated by the solid-phase or liquid-phase extraction techniques [121-124, 129-143] and extrelut extraction [144]. These methods have some drawbacks, including the need of large volume plasma extraction [133-135], poor recovery $[136,137]$, utilization of an internal standard that is not commercially available $[135,138]$, requirement of an additional protonation step [139], low capabilities of urine analysis [133, $139,140]$, and triple extraction $[142,143]$ which were time consuming. HPLC method presented by Jantratid et al. [145] for the estimation of CIM in human plasma involves a simplified sample preparation by protein precipitation with perchloric acid.

Iqbal et al. [146] reported an HPLC method for CIM in biological fluids. Plasma sample preparation needs liquid extraction with water-saturated ethyl acetate. After extraction, extracts were evaporated under nitrogen and reconstituted with mobile phase. Advantages of this validated assay over other reported methods include a simple plasma extraction and urine dilution procedures and willingly available internal standard and applicability to clinical studies. Sample cleanup and analysis of CIM in urine and blood were described by Apffel and his friends [147], sample preparations were achieved by adsorption technique on Waters Sep-pak C18 disposable precolumns, and the separation was performed on a RP column. Dong-Sun et al. [148] presented an analytical work saving online-column switching HPLC method with UV detection for cleanup and analysis. Gomita et al. [149] established an HPLC method for microdetermination of CIM in rat plasma. Betto et al. [121] developed an HPLC method with diode-array detector in order to assay CIM and its related impurities in pharmaceutical formulations. 
TABLE 3: Application of HPLC to the determination of $\mathrm{H}_{2}$ receptor antagonists.

\begin{tabular}{|c|c|c|c|}
\hline Column & Mobile phase & Detection & Ref. \\
\hline $250 \times 4.6 \mathrm{~mm}$ I.D Nucleosil $\mathrm{C}_{18}(5 \mu \mathrm{m})$ packed by Chromex & ACN : phosphate buffer, pH $6.2(25: 75, \mathrm{v} / \mathrm{v})$ & $228 \mathrm{~nm}$ & {$[137]$} \\
\hline $\begin{array}{l}\text { Phenomenex (Torrance, CA) C18 }(4.6 \times 250 \mathrm{~mm}) \text {, } \\
\text { Prodigy5_m ODS (3), } 100\end{array}$ & $\begin{array}{l}\text { ACN : heptanesulfonic acid } 20 \mathrm{mM} \text { sodium acetate } \\
\text { buffer }(23: 77)\end{array}$ & $228 \mathrm{~nm}$ & {$[146]$} \\
\hline$\mu$-Bondapak $\mathrm{C}_{18}$ column & $\begin{array}{l}21 \mathrm{mM} \text { disodium hydrogen } \\
\text { phosphate : triethylamine : ACN }(1000: 60: 150, \mathrm{v} / \mathrm{v}) \text {, } \\
\text { pH 3.5. }\end{array}$ & $320 \mathrm{~nm}$ & {$[160]$} \\
\hline Supelcosil LC-CN column $(5 \mu \mathrm{m}, 250 \times 4.6$ mm I.D. $)$ & $\begin{array}{l}\text { 0.05 M potassium dihydrogen phosphate : ACN }(88: 12 \text {, } \\
\text { v/v) pH } 6.5\end{array}$ & $229 \mathrm{~nm}$ & {$[162]$} \\
\hline $\begin{array}{l}\text { Spherisorb phenyl cartridge column, } 10 \mathrm{~cm} \times 0.46 \mathrm{~cm} \text { I.D., } \\
5 \mu \mathrm{m} \text { particle diameter }\end{array}$ & $\begin{array}{l}88-89 \% \text { of } 0.02 \mathrm{M} \text { phosphate buffer } \mathrm{pH} 3 \text { and } 11-12 \% \text { of } \\
\text { methanol }\end{array}$ & $228 \mathrm{~nm}$ & {$[167]$} \\
\hline Cation-exchange column & $\begin{array}{l}0.1 \mathrm{M} \text { sodium acetate buffer } \\
(\mathrm{pH} 5): \text { CAN : tetrahydrofuran }(56.5: 36: 7.5, \mathrm{v} / \mathrm{v})\end{array}$ & $230 \mathrm{~nm}$ & {$[172]$} \\
\hline $5-\mu \mathrm{m}$ ODS silica & $\begin{array}{l}\text { ACN-7 mM triethylammonium ion in phosphoric acid, } \\
\text { pH } 3.0(30: 70 \mathrm{v} / \mathrm{v}) \text {. }\end{array}$ & $315 \mathrm{~nm}$ & [173] \\
\hline Nucleosil C18 column & $\begin{array}{l}\text { Ammonium acetate solution }(0.5 \mathrm{M}) \text {, acetonitrile, and } \\
\text { methanol }\end{array}$ & $254 \mathrm{~nm}$ & {$[176]$} \\
\hline $\begin{array}{l}\text { Phenomenex (Torrance, CA, USA) Prodigy ODS ( } 3 \text { ) }(5 \mathrm{~mm} \\
\text { particle size, } 25 \mathrm{~cm} \times 3.9 \mathrm{~mm} \text { I.D.) reversed-phase HPLC } \\
\text { column }\end{array}$ & $\begin{array}{l}\text { ACN and heptanesulfonic acid }\left(2.5 \mathrm{gL}^{-1}\right) \text { in } 20 \mathrm{mM} \\
\text { sodium acetate buffer }(23: 77) \text {. }\end{array}$ & $267 \mathrm{~nm}$ & [191] \\
\hline Supelcosil LC18 column & $\begin{array}{l}\mathrm{ACN}: 0.1 \mathrm{M} \text { dihydrogen phosphate buffer containing } \\
0.2 \% \text { triethylamine, }(13: 87 \mathrm{v} / \mathrm{v}), \mathrm{pH} 3.0\end{array}$ & $265 \mathrm{~nm}$ & {$[206]$} \\
\hline Octadecyl silane-bonded silica column & Methanol : $0.02 \mathrm{M}$ sodium acetate $(\mathrm{pH} 4.5)(1: 4)$ & $254 \mathrm{~nm}$ & {$[209]$} \\
\hline Porous graphitic carbon (PGC) column & $\begin{array}{l}\text { ACN : water containing } 0.5 \% \text { pentane sulphonic acid, } \\
(50: 50 \mathrm{v} / \mathrm{v})\end{array}$ & $265 \mathrm{~nm}$ & {$[210]$} \\
\hline
\end{tabular}

\subsection{Ranitidine}

4.3.1. Spectrophotometric Methods. Three spectrophotometric methods for the determination of RAN involve formation and solving of simultaneous equations, making use of first-order derivative spectroscopy and two wavelength calculations presented by Pillai and Singhvi [150]. Kinetic spectrophotometric method involves the reaction of the drugs with alkaline potassium permanganate, and green color is produced peaking at $610 \mathrm{~nm}$. The reaction is monitored by measuring the rate of change of absorbance of the resulting manganate species [151]. Another kinetic method described by Walash et al. [152] for RAN and NIZ based on the reaction of the compounds with 7-chloro-4-nitrobenz-2-oxa-1,3diazole in borate buffer $\left(\mathrm{pH} 7.4\right.$ ) at $60^{\circ} \mathrm{C}$ for $25 \mathrm{~min}$ and the reaction product is measured at $495 \mathrm{~nm}$. The protolytic constants of RAN and NIZ were studied using a spectrophotometric method [153]. Four new methods established by Basavaiah and Nagegowda [154] using titrimetry and visible spectrophotometry with potassium bromate as the oxidimetric reagent and acid dyes, methyl orange, indigo carmine, and metanil yellow. Determination of RAN and NIZ through charge transfer complex formation with either $\mathrm{p}$ chloranilic acid or 2,3 dichloro-5,6-dicyanoquinone (DDQ) and the colored products are quantified at 515 and $467 \mathrm{~nm}$ in chloranilic acid and DDQ methods, respectively [155]. Charge-transfer complexation method for RAN, FAM, and
NIZ is based on interaction of these drugs with 7,7,8,8-tetracyanoquinodimethane to give green-colored radical anions that are deliberate at $840 \mathrm{~nm}$ [156].

4.3.2. HPLC Methods. Literature showed that a variety of HPLC methods have been reported for the estimation of RAN (Table 3 ) in biological fluids by using a short polymeric chain [157], silica-based column [158], polymeric base reversedphase column [159], without solvent extraction or one-step sample preparation [158, 160-162], two-step extraction [163], two solvents combination for extraction [164], protein precipitation and salting out procedures [157], solid-phase extraction [165-167], liquid-liquid extraction with organic solvents [168-170], and ion-pair high-performance liquid chromatography [161, 163]. Farthing et al., [171] reported a HPLC method for RAN in human plasma by solid-phase extraction and midbore chromatographic technique.

Prueksaritanont et al. [172], Rahman et al., [173], and Viñas et al. [174] established sensitive methods for the concurrent determination of RAN and its metabolites (RAN Noxide, RAN S-oxide, and desmethylranitidine) in human plasma and urine. Lant et al. [175] developed an assay for RAN and all the above metabolites in biological fluids by a postcolumn fluorimetric derivatization. Quantitative as well as qualitative analysis of RAN and its metabolites were determined by a direct liquid introduction-RP HPLC-mass spectrometry system [176]. 
Kokoletsi and his companions [176] presented a method for the simultaneous determination of RAN, methylparaben, and propylparaben in oral liquids. Purifications of samples were carried out by solid-phase extraction using a copolymeric sorbent.

\subsection{Famotidine}

4.4.1. Spectrophotometric Methods. Amin and his companions [177] reported three selective spectrophotometric methods for the determination of FAM through oxidation with $n$-bromosuccinimide and ceric sulphate by measuring the absorbance at 521 and $(528,526) \mathrm{nm}$, respectively. Dissolution test for FAM tablets was optimized using a simple direct spectrophotometric flow injection assay $\left(\lambda_{\max } 265 \mathrm{~nm}\right)$ that has also been fully validated in terms of linearity, limit of detection, precision, selectivity, and accuracy [178]. Different UV spectrophotometric methods have been reported for the determination of FAM in pharmaceutical formulations based on the reaction of FAM with 1,4-benzoquinone [179] and sodium nitroprusside [180], interaction of FAM with ninhydrin [181] and $p$-chloranilic acid [182], charge transfer complexation with chloranil, 2,3-dichloro 5,6-dicyano 1,4-benzoquinone and dichloronitrophenol [183], measuring the peak height of the second derivative [184], ion-pair complex formation with bromocresol green and bromothymol blue [185, 186], and difference spectrophotometric and quadratic polynomial coefficient methods [187].

4.4.2. HPLC Methods. Literature survey showed that a number of HPLC methods have been reported for the individual and simultaneous determination of FMT [188-192] and of all related compounds (Table 3) [193-199]. Majority of methods utilized either solid phase or liquid-liquid extraction techniques [200-203]. Extensive methods were reported [204, 205] for FAM in which HPLC separation with columnswitching technique was applied. RP-HPLC method for the determination of FAM and its potential impurities in dosage forms were performed on a Supelcosil C18 column with an isocratic mobile phase. Response was linearly dependent on concentration $1-80 \mu \mathrm{g} \mathrm{mL}^{-1}$ (regression coefficient, $R^{2}$ from 0.9981-0.9999) [206]. Carlucci et al. [207] established an RPHPLC and second-derivative ultraviolet spectra in finished product by utilizing the linear relationship between concentration and derivative peak amplitude. Campanero et al. [190] presented a liquid chromatography-electrospray ionization mass spectrometric detection with a rapid and well-organized sample refine method for the estimation of FAM in human plasma. Assay method using a monolithic column has been developed for quantification of FAM in plasma and enables the measurement of FAM for therapeutic drug monitoring with a minimum detectable limit of $5 \mathrm{ng} \mathrm{mL}^{-1}$ [208].

Stability-indicative liquid chromatographic analysis and degradation kinetics of FAM in tablets are described by Kamath and friends [209]. Another stability-indicating assay was demonstrated for the simultaneous determination of FAM and related impurities in pharmaceuticals using porous graphitic carbon column [210].
4.5. Simultaneous Determination of $\mathrm{H}_{2}$ Receptor Antagonists. Literature shows several articles published for the simultaneous determination of $\mathrm{H}_{2}$ receptor antagonists (cimitedine, ranitidine, and famotidine) with other categories of drug classes (Table 4). An HPLC method on fourth-generation fluoroquinolones that is, gemifloxacin and cimetidine, ranitidine and famotidine was established the presence of getifloxacin as an internal standard by the Pakistani authors. Mobile phase was delivered isocratically at ambient temperature. Quantitation was performed at three different wavelengths, that is, 221, 256, and $267 \mathrm{~nm}$ as well as statistical analysis such that Student's $t$-test and Friedman's were also functional to compare these outcomes [211]. Naveed et al. [212] presented a RP-HPLC method for the simultaneous determination of lisinopril and all three $\mathrm{H}_{2}$ receptor antagonists. Separation was performed isocratically with $1.0 \mathrm{~mL} \mathrm{~min}^{-1}$ flow rate over the concentration range of 2.5-100 and 0.7$12.50 \mu \mathrm{g} \mathrm{mL}^{-1}$ for $\mathrm{H}_{2}$ receptor antagonists and lisinopril, respectively, with regression value of \pm 0.999 . In the same way captopril, a specific ACE inhibitor, was quantitatively determined by the RP-HPLC technique with CIM, RAN, and FAM. For method optimization different mixtures of mobile phase were tried and retention time, resolution, and peak symmetry were also taken into consideration for system suitability. Later on the validated method was efficiently verified for in vitro interaction studies [213]. Arayne et al. [214] also developed and validated a high-performance liquid chromatographic method for metformin, ranitidine, famotidine, and cimetidine in their synthetic mixtures and dosage forms. Calibration curve was constructed in the concentration range of $5-25 \mu \mathrm{g} \mathrm{mL}^{-1}$ with $0.997-0.9998 r^{2}$ values. Inter-and intraday precision and accuracy were less than $2 \%$ and $98.6-$ $102.4 \%$, respectively. Another sensitive and selective liquid chromatographic method was published for the prazosin, CIM, RAN, and FAM by Najma et al. [215] as per (ICH) guidelines. Mobile phase was pumped in column through isocratic mode. Total run time of analysis was less than five minutes that is important for quality control analysis and clinical laboratories. Similarly, an HPLC method for the simultaneous estimation of a fluoroquinolone sparfloxacin and above $\mathrm{H}_{2}$ receptor antagonists was also reported in bulk, dosage form, and human serum. The demonstrated method was specific as there is no interference found from the spike matrix and serum. Accuracy and precision of the method were found in acceptable boundary $98.02-102.136 \%$ and $0.5-$ $2.2 \%$, respectively. Statistical Paired $t$-test was applied for the verification of the collected data [216]. HPLC simultaneous determination of CIM, RAN, FAM, and NIZ was established using a two-level, full-factorial design with three variables (volume of methanol, percentage of triethylamine, and concentration of phosphate buffer). None of the commercial samples was found to be outside the compendial limits of 90-110.0\% of the claim amount [217]. HPLC method for CIM and RAN in plasma sample was investigated by cleanup procedure that used solid-phase extraction and separated on a Lichrocart Lichrospher $60 \mathrm{RP}$-select B column. The effects of organic modifiers, mobile phase composition, $\mathrm{pH}$, and buffer concentration on retention time of analytes were also investigated [218]. 
TABLE 4: Application of HPLC to the simultaneous determination of $\mathrm{H}_{2}$ receptor antagonists.

\begin{tabular}{|c|c|c|c|}
\hline Column & Mobile phase & Detection (nm) & Ref. \\
\hline RP-mediterranea column C18 $(250 \times 4.6 \mathrm{~mm}, 5 \mu \mathrm{m})$ & $\begin{array}{l}\text { ACN : methanol : water }(20: 28: 52 \mathrm{v} / \mathrm{v} / \mathrm{v}), \mathrm{pH} 2.8 \\
\text { adjusted by phosphoric acid }\end{array}$ & 221,256 and 267 & {$[211]$} \\
\hline $\begin{array}{l}\text { Hypersil, ODS, C18 (150 } 94.6 \mathrm{~mm}, 5 \mathrm{~lm}) \text { and } \\
\text { Purospher_STAR RP-18 column }\end{array}$ & $\begin{array}{l}\mathrm{ACN}: \text { water }(70: 25 \mathrm{v} / \mathrm{v}) \mathrm{pH} \text { adjusted to } 3.0 \text { by } \\
\text { phosphoric acid }\end{array}$ & 225 & {$[212]$} \\
\hline Purospher star C18 $(5 \mu \mathrm{m}, 25 \times 0.46 \mathrm{~cm})$ column & $\begin{array}{l}\text { methanol: water }(60: 40 \mathrm{v} / \mathrm{v}), \mathrm{pH} \text { adjusted to } 3.0 \pm 0.02 \\
\text { by phosphoric acid }\end{array}$ & 225 & {$[21$} \\
\hline $\begin{array}{l}\text { Purospher Star RP18 endcapped }(250 \mathrm{~mm} \times 4.6 \mathrm{~mm} \text { I.D. }) \\
\text { column packed with } 5-\mu \mathrm{m} \text { particles. }\end{array}$ & $\begin{array}{l}\text { Methanol-water-triethylamine } \\
(20: 80: 0.05) \text {, whose } \mathrm{pH} \text { was adjusted to } 3.0 \text { with } \\
\text { phosphoric acid }\end{array}$ & 229 & {$[214$} \\
\hline Nucleosil, $100-10$, C-18 column $(250 \times 4.6 \mathrm{~mm}, 10$ micron $)$ & Methanol : water : acetonitrile (60: $45: 5 \mathrm{v} / \mathrm{v}, \mathrm{pH} 3.83)$ & 240 & {$[21$} \\
\hline Purospher STAR $\mathrm{C}_{18}(250 \times 4.6 \mathrm{~mm}, 5 \mu \mathrm{m})$ column & $\begin{array}{l}\text { Methanol: water : ACN }(54: 41: 5 \mathrm{v} / \mathrm{v} / \mathrm{v}) \mathrm{pH} 2.7 \\
\text { adjusted by phosphoric acid }\end{array}$ & 232 and 250 & {$[216$} \\
\hline$(15 \mathrm{~cm} \times 4.6 \mathrm{~mm}$ ID) of Inertsil ODS-2 $(5 \mu \mathrm{m})$ column & $\begin{array}{l}0.04 \mathrm{M} \text { aqueous sodium dihydrogen } \\
\text { phosphate : ACN : methanol: TEA ( } 345: 20: 35: 0.7 \\
\text { v/v/v/v) }\end{array}$ & $230 \mathrm{~nm}$ & [217] \\
\hline
\end{tabular}

\section{Conclusion}

In this paper UV and HPLC methods for the determination of diltiazem and three $\mathrm{H}_{2}$-receptor antagonists in bulk material, pharmaceutical formulations and biological specimens are reviewed. Spectrophotometric techniques provided practical (less-time-consuming, simpler, and more convenient) and significant economic advantages over other methods; therefore, they are a frequent choice for pharmaceutical analyses. HPLC methods generally required complex and expensive equipment, provision for use and disposal of solvents, laborintensive sample preparation procedure, and personal skills in chromatographic techniques. In addition, most of the HPLC methods reviewed have the potential application to clinical research of drug combination, multidrug pharmacokinetics, and interactions.

\section{References}

[1] D. Colin, Therapeutic Drug, Churchill Livingstone, Division of Longman Group, London, UK, 2nd edition, 1999.

[2] S. C. Sweetman, Martindale, the Complete Drug Reference, Pharmaceutical Press, 33rd edition, 2002.

[3] E. Jantratid, S. Prakongpan, J. B. Dressman et al., "Biowaiver monographs for immediate release solid oral dosage forms: cimetidine," Journal of Pharmaceutical Sciences, vol. 95, no. 5, pp. 974-984, 2006.

[4] B. A. Hendriksen, M. V.S. Felix, and M. B. Bolger, "The composite solubility versus $\mathrm{pH}$ profile and its role in intestinal absorption prediction," AAPS PharmSci, vol. 5, no. 1, article E4, 2003.

[5] J. G. Hardman, L. E. Limbird, and A. G. Gilman, Eds., Goodman \& Gilman's The Pharmacological Basis of Therapeutics, McGrawHill, New York, NY, USA, 10th edition, 2001.

[6] C. Martínez, C. Albet, J. A. G. Agúndez et al., "Comparative in vitro and in vivo inhibition of cytochrome P450 CYP1A2, CYP2D6, and CYP3A by $\mathrm{H}_{2}$-receptor antagonists," Clinical Pharmacology \& Therapeutics, vol. 65, no. 4, pp. 369-376, 1999.

[7] N. R. Peden, J. H. B. Saunders, and K. G. Wormsley, "Inhibition of pentagastrin-stimulated and nocturnal gastric secretion by ranitidine, a new $\mathrm{H}_{2}$-receptor antagonist," The Lancet, vol. 1, no. 8118, pp. 690-692, 1979.

[8] C. W. Howden and G. N. J. Tytgat, "The tolerability and safety profile of famotidine," Clinical Therapeutics, vol. 18, no. 1, pp. 36-54, 1996.

[9] H. D. Maples, L. P. James, C. D. Stowe et al., "Famotidine disposition in children and adolescents with chronic renal insufficiency," Journal of Clinical Pharmacology, vol. 43, no. 1, pp. 7-14, 2003.

[10] United States Pharmacopeia 30, National Formulary 25, Official Monographs, The United States Pharmacopeial Convention, Rockville, Md, USA, 2007.

[11] D. J. Mazzo, C. L. Obetz, and J. Shuster, "Diltiazem hydrochloride," Analytical Profiles of Drug Substances and Excipients, vol. 23, pp. 53-98, 1994.

[12] P. M. G. Bavin, A. Post, J. E. Zarembo et al., "Cimetidine," in Analytical Profiles of Drug Substances, K. Florey, Ed., vol. 13, pp. 127-183, Academic Press, Orlando, Fla, USA, 30th edition, 1984.

[13] M. Hohnjec, J. Kuftinec, M. Malnar et al., "Ranitidine," in Analytical Profiles of Drug Substances, K. Florey, Ed., vol. 15, pp. 533-561, Academic Press, New York, NY, USA, 1986.

[14] European Pharmacopoeia, Council of Europe, Strasbourg, France, 4th edition, 2002.

[15] “The United State Pharmacopoea," vol. 34, pp. 2581-2586, 2011.

[16] “The United State Pharmacopoea," vol. 34, pp. 2337-2340, 2011.

[17] “The Birtish Pharmacopoea," 6th edition, pp. 2602-2605, 2011.

[18] “The United State Pharmacopoea," vol. 34, pp. 3258-3261, 2011.

[19] “The United State Pharmacopoea," vol. 34, pp. 2792-2796, 2011.

[20] “The Birtish Pharmacopoea," 6th edition, pp. 2805-2806, 2011.

[21] “The Birtish Pharmacopoea," 6th edition, pp. 3258-3261, 2011.

[22] C. Georgita, F. Albu, V. David, and A. Medvedovici, "Nonlinear calibrations on the assay of dilitiazem and two of its metabolites from plasma samples by means of liquid chromatography and ESI/MS2 detection: application to a bioequivalence study," Biomedical Chromatography, vol. 22, no. 3, pp. 289-297, 2008.

[23] B. K. Matuszewski, M. L. Constanzer, and C. M. Chavez-Eng, "Strategies for the assessment of matrix effect in quantitative bioanalytical methods based on HPLC-MS/MS," Analytical Chemistry, vol. 75, no. 13, pp. 3019-3030, 2003. 
[24] R. Dams, M. A. Huestis, W. E. Lambert, and C. M. Murphy, "Matrix effect in bio-analysis of illicit drugs with LC-MS/MS: influence of ionization type, sample preparation, and biofluid," Journal of the American Society for Mass Spectrometry, vol. 14, no. 11, pp. 1290-1294, 2003.

[25] J. P. Clozel, G. Caillé, Y. Taeymans, P. Théroux, P. Biron, and J. G. Besner, "Improved gas chromatographic determination of diltiazem and deacetyldiltiazem in human plasma," Journal of Pharmaceutical Sciences, vol. 73, no. 2, pp. 207-209, 1984.

[26] O. Grech-Belanger, E. Leboeuf, and S. Langlois, "A gas chromatographic method for the analysis of diltiazem in plasma," Journal of Chromatography, vol. 417, no. 1, pp. 89-98, 1987.

[27] R.T. Sane, M. Purandare, G. Nayak et al., "Gas chromatographic determination of diltiazem hydrochloride in pharmaceuticals," Indian Drugs, vol. 26, no. 11, pp. 623-625, 1989.

[28] M. Nishikawa, A. Ishii, K. Watanabe, H. Seno, T. Kumazawa, and O. Suzuki, "Determination of diltiazem in body fluids by gas chromatography with surface ionization detection," Japanese Journal of Forensic Toxicology, vol. 12, no. 3, pp. 247-251, 1994.

[29] H. R. Ochs and M. Knuchel, "Pharmacokinetics and absolute bioavailability of diltiazem in humans," Klinische Wochenschrift, vol. 62, no. 7, pp. 303-306, 1984.

[30] M. M. Ayad, H. E. Abdellatef, M. M. Hosny, Y. A. Sharaf et al., "Application of 4-chloro-7-nitrobenzofurazan for the analysis of propafenone and diltiazem hydrochlorides using kinetic spectrophotometric and spectrofluorimetric methods," European Journal of Chemistry, vol. 4, no. 1, pp. 35-43, 2013.

[31] M. M. Hosny, "Spectrophotometric determination of diltiazem, fluphenazine and dothiepin hydrochlorides using chromotrope 2R and rose bengal," Mansoura Journal of Pharmaceutical Sciences, vol. 20, pp. 64-77, 2004.

[32] R. Bindu and A. K. Chandrasekharan, "Colorimetric determination of diltiazem hydrochloride in pharmaceutical formulations," Indian Drugs, vol. 31, no. 4, pp. 168-169, 1994.

[33] R. Pietraś, D. Kowalczuk, and H. Hopkała, "Comparison of classical and derivative UV-spectrophotometric methods for the quantification of diltiazem and mexiletine," Acta Poloniae Pharmaceutica, vol. 61, no. 5, pp. 315-320, 2004.

[34] L. Z. L. Sabino, D. C. Marino, and H. D. Moya, "Determination of diltiazem based on the reduction of $\mathrm{Cu}$ (II)-BCA complexes in micellar medium," Canadian Journal of Chemistry, vol. 88, no. 6, pp. 533-539, 2010.

[35] N. Rahman, S. N. H. Azmi, and Y. Ahmad, "Quantitation of diltiazem hydrochloride in commercial dosage forms by visible spectrophotometry," Journal of the Chinese Chemical Society, vol. 54, pp. 419-430, 2007.

[36] J. M. M. Leitãoa and J. C. G. Esteves da Silva, "Factorial analysis optimization of a Diltiazem kinetic spectrophotometric quantification method," Analytica Chimica Acta, vol. 609, no. 1, pp. $1-12,2008$.

[37] N. Rahman and S. N. H. Azmi, "Spectrophotometric determination of diltiazem hydrochloride with sodium metavanadate," Microchemical Journal, vol. 65, no. 1, pp. 39-43, 2000.

[38] M. M. Ayad, A. Shalaby, H. E. Abdellatef, and M. M. Hosny, "New colorimetric methods for the determination of trazodone $\mathrm{HCl}$, famotidine, and diltiazem $\mathrm{HCl}$ in their pharmaceutical dosage forms," Analytical and Bioanalytical Chemistry, vol. 376, no. 5, pp. 710-714, 2003.

[39] A. M. El-Didamony, "Indirect spectrophotometric determination of diltiazem hydrochloride in pure form and pharmaceutical formulations," Central European Journal of Chemistry, vol. 3, no. 3, pp. 520-536, 2005.
[40] D. Zivanov-Stakic, D. Agbaba, S. Vladimirov, and L. J. Ciric, "Spectrophotometric determination of diltiazem in dosage forms," Farmaco, vol. 47, no. 3, pp. 393-396, 1992.

[41] Y. K. Agrawal, K. Shivramachandra, and B. E. Rao, "Spectrophotometric methods for the determination of diltiazem in pharmaceutical preparations," Indian Journal of Pharmaceutical Sciences, vol. 54, no. 6, pp. 218-221, 1992.

[42] B. V. Kamath and K. Shivram, "Extractive spectrophotometric method for the determination of diltiazem hydrochloride in its dosage forms," Indian Drugs, vol. 29, no. 1, pp. 50-52, 1991.

[43] B. V. Kamath, K. Shivram, and A. C. Shah, "Selective spectrophotometric determination of diltiazem hydrochloride in tablets," Journal of Pharmaceutical and Biomedical Analysis, vol. 11, no. 4-5, pp. 407-409, 1993.

[44] K. Sreedhar, C. S. P. Sastry, M. Narayana Reddy, and D. G. Sankar, "Extractive spectrophotometric determinations of diltiazem hydrochloride," Indian Drugs, vol. 32, no. 2, pp. 90-92, 1995.

[45] N. Rahman and S. N. Hejaz-Azmi, "Extractive spectrophotometric methods for determination of diltiazem $\mathrm{HCl}$ in pharmaceutical formulations using bromothymol blue, bromophenol blue and bromocresol green," Journal of Pharmaceutical and Biomedical Analysis, vol. 24, no. 1, pp. 33-41, 2000.

[46] H. A. Abu-Shadi, S. T. Hasib, H. H. Hassanein, and A. Abadi, "Spectrophotometric determination of some cardiovascular drugs," Egyptian Journal of Pharmaceutical Sciences, vol. 36, no. 1-6, pp. 393-405, 1995.

[47] S. Dadashzadeh, A. Zarghi, and A. J. Ebrahimian, "Pharmacokinetics and comparative bioavailability of two diltiazem tablet formulations in healthy volunteers," Daru, vol. 11, no. 1, pp. 14$18,2003$.

[48] R. K. Gilpin and L. A. Pachla, "Pharmaceuticals and related drugs," Analytical Chemistry, vol. 73, no. 12, pp. 2805-2816, 2001.

[49] A. M. Krstulovic and C. R. Lee, "Defining drug purity through chromatographic and related methods: current status and perspectives," Journal of Chromatography B, vol. 689, no. 1, pp. 137-153, 1997.

[50] R. Pravin Cumar, M. Vasudevan, and D. Raman, "RP-HPLC method development and validation for the estimation of diltiazem in bulk and tablet dosage forms," Asian Journal of Pharmaceutical and Clinical Research, vol. 5, no. 3, pp. 62-64, 2012.

[51] N. Sultana, M. S. Arayne, N. Shafi et al., "A validated method for the analysis of diltiazem in raw materials and pharmaceutical formulations by RP-HPLC," Pakistan Journal of Pharmaceutical Sciences, vol. 20, no. 4, pp. 279-284, 2007.

[52] A. S. Sidhu, J. M. Kennedy, and S. Deeble, "General method for the analysis of pharmaceutical dosage forms by high-performance liquid chromatography," Journal of Chromatography, vol. 391, no. 1, pp. 233-242, 1987.

[53] P. M. Lacroix, N. Beaulieu, T. D. Cyr, and E. G. Lovering, "Highperformance liquid chromatography method for assay of diltiazem hydrochloride and its related compounds in bulk drug and finished tablets," Journal of Pharmaceutical Sciences, vol. 78, no. 3, pp. 243-246, 1989.

[54] D. Zendelovska, S. Simeska, S. Petrov, and P. Milosevski, "A sensitive method for determination of famotidine in human plasma by HPLC and its application for bioequivalence studies," Acta Pharmaceutica, vol. 52, no. 2, pp. 113-120, 2002.

[55] D. Zendelovska, T. Stafilov, and S. Petrov, "Simultaneous quantification of cefaclor and cephalexine in blood plasma using 
high-performance liquid chromatography with UV detection," Acta Pharmaceutica, vol. 52, no. 4, pp. 243-250, 2002.

[56] D. Zendelovska, T. Stafilov, and M. Stefova, "Optimization of a solid-phase extraction method for determination of indapamide in biological fluids using high-performance liquid chromatography," Journal of Chromatography B, vol. 788, no. 1, pp. 199206, 2003.

[57] K. Li, X. Zhang, and F. Zhao, "HPLC determination of diltiazem in human plasma and its application to pharmacokinetics in humans," Biomedical Chromatography, vol. 17, no. 8, pp. 522525, 2003.

[58] C. D. Kinney and J. G. Kelly, "Estimation of concentrations of diltiazem in plasma using normal-phase column liquid chromatography with ultraviolet detection," Journal of Chromatography $B$, vol. 382, pp. 377-381, 1986.

[59] R. S. Chaudhary, S. S. Gangwal, M. K. Avachat, Y. N. Shah, and K. C. Jindal, "Determination of diltiazem hydrochloride in human serum by high-performance liquid chromatography," Journal of Chromatography B, vol. 614, no. 2, pp. 261-266, 1993.

[60] B. H. Jensen and C. Larsen, "Quantitation of diltiazem in human plasma by HPLC using an end-capped reversed-phase column," Acta Pharmaceutica Nordica, vol. 3, no. 3, pp. 179-180, 1991.

[61] M. Delwar Hussain, Y. K. Tam, B. A. Finegan, and R. T. Coutts, "Simple and sensitive high-performance liquid chromatographic method for the determination of diltiazem and six of its metabolites in human plasma," Journal of Chromatography $B$, vol. 582, no. 1-2, pp. 203-209, 1992.

[62] C. Verghese, M. S. Smith, L. Aanonsen, E. L. Pritchett, and D. G. Shand, "High-performance liquid chromatographic analysis of diltiazem and its metabolite in plasma," Journal of Chromatography, vol. 272, no. 1, pp. 149-155, 1983.

[63] K.-J. Goebel and E. U. Kolle, "High-performance liquid chromatographic determination of diltiazem and four of its metabolites in plasma. Application to pharmacokinetics," Journal of Chromatography B, vol. 345, no. 2, pp. 355-363, 1985.

[64] L. M. Dube, N. Mousseau, and I. J. McGilveray, "High-performance liquid chromatographic determination of diltiazem and four of its metabolites in plasma: evaluation of their stability," Journal of Chromatography B, vol. 430, no. 1, pp. 103-111, 1988.

[65] D. Paczkowski, R. Dabrowski, D. Sitkiewicz, and Z. Sadowski, "Analysis of diltiazem and desacetyldiltiazem in serum by highperformance liquid chromatography," Polish Journal of Pharmacology, vol. 47, no. 5, pp. 429-434, 1995.

[66] G. Carignan, K. Carrier, S. Laganiere, and M. Lessard, "Simultaneous determination of diltiazem and quinidine in human plasma by liquid chromatography," Journal of Chromatography $B$, vol. 672, no. 2, pp. 261-269, 1995.

[67] P. Scully, E. Meehan, and J. G. Kelly, "High-performance liquid chromatographic assay for diltiazem in small-volume blood specimens and application to pharmacokinetic studies in rats," Journal of Chromatography A, vol. 729, no. 1-2, pp. 297-300, 1996.

[68] D. R. Rutledge, A. H. Abadi, L. M. Lopez, and C. A. Beaudreau, "High-performance liquid chromatographic determination of diltiazem and two of its metabolites in plasma using a short alkyl chain silanol deactivated column," Journal of Chromatography $B$, vol. 615, no. 1, pp. 111-116, 1993.

[69] V. Ascalone and L. Dal Bo, "Automated high-performance liquid chromatographic and column-switching technique for online clean-up and analysis of diltiazem in human plasma," Journal of Chromatography B, vol. 423, pp. 239-249, 1987.
[70] F. Mangani, G. Luck, C. Fraudeau, and E. Vérette, “On-line column-switching high-performance liquid chromatography analysis of cardiovascular drugs in serum with automated sample clean-up and zone-cutting technique to perform chiral separation," Journal of Chromatography A, vol. 762, no. 1-2, pp. 235241, 1997.

[71] P. Hubert, P. Chiap, and J. Crommen, "Automatic determination of diltiazem and desacetyldiltiazem in human plasma using liquid-solid extraction on disposable cartridges coupled to HPLC-Part I: optimization of the HPLC system and method validation," Journal of Pharmaceutical and Biomedical Analysis, vol. 9, no. 10-12, pp. 877-882, 1991.

[72] H. Christensen, E. Carlson, A. Asberg, L. Schram, and K. J. Berg, "A simple and sensitive high-performance liquid chromatography assay of diltiazem and main metabolites in renal transplanted patients," Clinica Chimica Acta, vol. 283, no. 1-2, pp. 63-75, 1999.

[73] V. Ascalone, M. Locatelli, and B. Malavasi, "Determination of diltiazem and its main metabolites in human plasma by automated solid-phase extraction and high-performance liquid chromatography: a new method overcoming instability of the compounds and interference problems," Journal of Chromatography B, vol. 657, no. 1, pp. 133-140, 1994.

[74] D. Zendelovska, T. Stafilov, M. Stefova et al., "High-performance liquid chromatographic determination of diltiazem in human plasma after solid-phase and liquid-liquid extraction," Analytical and Bioanalytical Chemistry, vol. 376, no. 6, pp. 848853, 2003.

[75] A. M. Rustum, "Determination of diltiazem in human whole blood and plasma by high-performance liquid chromatography using a polymeric reversed-phase column and utilizing a salting-out extraction procedure," Journal of Chromatography B, vol. 490, no. 2, pp. 365-375, 1989.

[76] R. Boulieu, J. L. Bonnefous, and S. Ferry, "Determination of diltiazem and its metabolites in plasma by high performance liquid chromatography," Journal of Liquid Chromatography, vol. 13, no. 2, pp. 291-301, 1990.

[77] A. Zarghi, S. Dadashzadeh, and A. J. Ebrahimian, "HPLC quantification of diltiazem in plasma from man," Pharmacy and Pharmacology Communications, vol. 6, no. 8, pp. 341-343, 2000.

[78] M. Parissi-Poulou, G. Ismailos, and P. Macheras, "Modified HPLC analysis of diltiazem in plasma for pharmacokinetic studies," International Journal of Pharmaceutics, vol. 62, no. 23, pp. R13-R16, 1990.

[79] P. K. F. Yeung, T. J. Montague, B. Tsui, and C. McGregor, "Highperformance liquid chromatographic assay of diltiazem and six of its metabolites in plasma: application to a pharmacokinetic study in healthy volunteers," Journal of Pharmaceutical Sciences, vol. 78, no. 7, pp. 592-597, 1989.

[80] N. Sultana, M. S. Arayne, N. Shafi, F. A. Siddiqui, and A. Hussain, "Development of a RP-HPLC method for the simultaneous analysis of diltiazem and statin: application in pharmaceuticals and human serum," Analytical Methods, vol. 2, no. 10, pp. 15711576, 2010.

[81] A. S. Kulkarni, S. D. Jadhav, S. S. Khetmar, and M. S. Bhatia, "Development of chromatographic technique for simultaneous estimation of lovastatin and diltiazem hydrochloride," Mahidol University Journal of Pharmaceutical Sciences, vol. 39, no. 3-4, pp. 17-23, 2012.

[82] N. Sultana, M. S. Arayne, N. Shafi, F. A. Siddiqui, and A. Hussain, "Development and validation of new assay method for the simultaneous analysis of diltiazem, metformin, pioglitazone 
and rosiglitazone by RP-HPLC and its applications in pharmaceuticals and human serum," Journal of Chromatographic Science, vol. 49, no. 10, pp. 774-779, 2011.

[83] N. Sultana, M. S. Arayne, N. Shafi, and F. A. Siddiqui, "Simultaneous RP-LC analysis of diltiazem and non-steroidal antiinflammatory drugs in pharmaceutical formulations and human serum," Chromatographia, vol. 71, no. 1-2, pp. 71-77, 2010.

[84] N. Sultana, M. S. Arayne, N. Shafi, N. Asia, S. Naz, and H. Shamshad, "A RP-HPLC method for the simultaneous determination of diltiazem and quinolones in bulk, formulations and human serum," Journal of the Chilean Chemical Society, vol. 54, no. 4, pp. 358-362, 2009.

[85] S. Naz, N. Sultana, M. S. Arayne, and N. Shafi, "Simultaneous determination of prazosin and calcium chanel blockers in raw materials, pharmaceutical formulations and human serum by RP-HPLC," International Journal of Pharma research and Development, vol. 2, no. 9, pp. 6-10, 2010.

[86] N. Sultana, M. S. Arayne, and N. Shafi, "In vitro interaction studies of diltiazem with $\mathrm{H}_{2}$ receptor antagonists," Medicinal Chemistry Research, vol. 19, no. 7, pp. 698-716, 2010.

[87] L. Jianchun, "RP-HPLC determination of diltiazem in plasma and pharmacokinetic parameter," pp. 12-15, 1992.

[88] C. Giachetti, P. Poletti, and G. Zanolo, "Analysis of calcium blocker drugs in plasma, HRGC and HPLC analytical conditions for pharmacokinetic studies," Journal of High Resolution Chromatography, vol. 10, no. 12, pp. 654-658, 1987.

[89] K. Li, X. Zhang, Y. Yuan, N. Luo, and L. Tan, "HPLC determination of diltiazem in human serum and its pharmacokinetic parameters," Chinese Journal of Chromatography, vol. 15, no. 5, pp. 451-453, 1997.

[90] R. Shimizu, K. Ishii, N. Tsumagari, M. Tanigawa, M. Matsumoto, and I. T. Harrison, "Determination of optical isomers in diltiazem hydrochloride by high-performance liquid chromatography," Journal of Chromatography A, vol. 253, no. 1, pp. 101108, 1982.

[91] G. Rosell, A. Camacho, and P. Parra, "Direct enantiomeric separation of cis- $( \pm)$ diltiazem in plasma by high-performance liquid chromatography with ovomucoid column," Journal of Chromatography B, vol. 619, no. 1, pp. 87-92, 1993.

[92] M. Shah, L. Sandler, V. Rai, C. Sharma, and L. Raghavan, "Quality of compounded topical $2 \%$ diltiazem hydrochloride formulations for anal fissure," World Journal of Gastroenterology, vol. 19, no. 34, pp. 5645-5650, 2013.

[93] K. Yaku, A. Keiichi, N. Nishimura, S. Tadashi, and F. Morishita, Supercritical Fluid Methods and Protocols, vol. 13 of Methods in Biotechnology, Humana Press, New York, NY, USA, 2000.

[94] I. Kazuhiro, M. Kenjirou, N. Noriyuki, M. Takaaki, and S. Tadashi, "Direct chromatographic resolution of four optical isomers of diltiazem hydrochloride on a chiralcel of column," Journal of Chromatography A, vol. 686, no. 1, pp. 93-100, 1994.

[95] H. Nishi, N. Fujimura, H. Yamaguchi, and T. Fukuyama, "Direct high-performance liquid chromatographic separation of the enantiomers of diltiazem hydrochloride and its 8-chloro derivative on a chiral ovomucoid column," Journal of Chromatography, vol. 633, no. 1-2, pp. 89-96, 1993.

[96] R. Shimizu, T. Kakimoto, I. Kazuhiro, Y. Fujimoto, H. Nishi, and $\mathrm{N}$. Tsumagari, "New derivatization reagent for the resolution of optical isomers in diltiazem hydrochloride by high-performance liquid chromatography," Journal of Chromatography A, vol. 357, no. 1, pp. 119-125, 1986.
[97] R. K. Bhamra, A. E. Ward, and W. Holt, "HPLC measurement of diltiazem and desacetyldiltiazem in serum or plasma," Biomedical Chromatography, vol. 2, no. 4, pp. 180-182, 1987.

[98] H. Zhao and M. S. Chow, "Analysis of diltiazem and desacetyldiltiazem in plasma using modified high-performance liquid chromatography: improved sensitivity and reproducibility," Pharmaceutical Research, vol. 6, no. 5, pp. 428-430, 1989.

[99] V. Ascalone and L. Flaminio, "Automated high-performance liquid chromatography with column switching for on-line cleanup and analysis of diltiazem and metabolites in human plasma," Journal of Chromatography B, vol. 495, pp. 358-360, 1989.

[100] R. Boulieu, J. L. Bonnefous, and S. Ferry, "Solid-phase extraction of diltiazem and its metabolites from plasma prior to highperformance liquid chromatography," Journal of Chromatography B, vol. 528, no. 2, pp. 542-546, 1990.

[101] K. E. Johnsona and J. A. Piepera, "An HPLC method for the determination of diltiazem and three of its metabolites in serum," Journal of Liquid Chromatography, vol.13, no. 5, pp. 951960, 1990.

[102] A. Leneveu, A. Stheneur, A. Bousquet, and A. Roux, "Automated high-performance liquid chromatographic technique for determining diltiazem and its three main metabolites in serum," Journal of Liquid Chromatography, vol. 14, no. 19, pp. 3519-3530, 1991.

[103] R. E. Wiens, D. J. Runser, J. P. Lacz, and D. C. Dimmitt, "Quantitation of diltiazem and desacetyldiltiazem in dog plasma by high-performance liquid chromatography," Journal of Pharmaceutical Sciences, vol. 73, no. 5, pp. 688-689, 1984.

[104] D. R. Abernethy, J. B. Schwartz, and E. L. Todd, "Diltiazem and desacetyldiltiazem analysis in human plasma using highperformance liquid chromatography: improved sensitivity without derivatization," Journal of Chromatography B, vol. 342, no. 1, pp. 216-220, 1985.

[105] D. Marini, G. Pollino, and F. Balestrieri, "Ditiazem: purification from related substances, and HPLC determination," Bollettino Chimico Farmaceutico, vol. 124, no. 3, pp. 138-145, 1985.

[106] S. C. Montamat, D. R. Abernethy, J. R. Mitchell et al., "High-performance liquid chromatographic determination of diltiazem and its major metabolites, N-monodemethyldiltiazem and desacetyldiltiazem, in plasma," Journal of Chromatography B, vol. 415, no. 1, pp. 203-207, 1987.

[107] P. Höglund and L. G. Nilsson, "Liquid chromatographic determination of diltiazem and its metabolites using trans isomers as internal standards, with dynamic modification of the solid phase by addition of an amine to the mobile phase," Journal of Chromatography B, vol. 414, no. 1, pp. 109-120, 1987.

[108] K. J. Goebel and E. U. Koelle, "High-performance liquid chromatographic determination of diltiazem and four of its metabolites in plasma: application to pharmacokinetics," Journal of Chromatography B, vol. 345, no. 2, pp. 355-363, 1985.

[109] L. T. Malaya, V. M. Brovkovich, and G. V. Andrievskii, "Analysis of diltiazem and its metabolites by HPLC and mass spectrometry," Pharmaceutical Chemistry Journal, vol. 24, no. 8, pp. 535537,1990

[110] F. F. T. Ververs, H. G. Schaefer, J. F. Lefeevre, L. M. Lopez, and H. Derendorf, "Simultaneous assay of propranolol, diltiazem and metabolites of diltiazem in human plasma by liquid chromatography," Journal of Pharmaceutical and Biomedical Analysis, vol. 8, no. 6, pp. 535-539, 1990.

[111] A. Tracqui, P. Kintz, and P. Mangin, "HPLC/MS determination of buprenorphine and norbuprenorphine in biological fluids 
and hair samples," Journal of Forensic Sciences, vol. 42, no. 1, pp. 111-114, 1997.

[112] Y. H. Lee, C. K. Shim, M. H. Lee, and S. K. Kim, "HPLC determination of diltiazem and deacetyldiltiazem in rat plasma," Journal of Korean Pharmaceutical Sciences, vol. 22, no. 4, pp. 317-321, 1992.

[113] B. Dasandi, S. Shah, and S. Shivprakash, "Development and validation of a high throughput and robust LC-MS/MS with electrospray ionization method for simultaneous quantitation of diltiazem and its two metabolites in human plasma: application to a bioequivalence study," Journal of Chromatography $B$, vol. 877, no. 8-9, pp. 791-798, 2009.

[114] A. R. Zoest, C. T. Hung, and S. Wanwimolruk, "Diltiazem: a sensitive HPLC assay and application to pharmacokinetic study," Journal of Liquid Chromatography, vol. 15, no. 8, pp. 1277-1287, 1992.

[115] I. A. Darwish, S. A. Hussein, A. M. Mahmoud, and A. I. Hassan, "A sensitive spectrophotometric method for the determination of $\mathrm{H}_{2}$-receptor antagonists by means of $\mathrm{N}$-bromosuccinimide and p-aminophenol," Acta Pharmaceutica, vol. 58, no. 1, pp. 8797, 2008.

[116] I. A. Darwish, S. A. Hussein, A. M. Mahmoud, and A.I. Hassan, "Spectrophotometric determination of $\mathrm{H}_{2}$-receptor antagonists via their oxidation with cerium(IV)," Spectrochimica Acta A, vol. 69, no. 1, pp. 33-40, 2008.

[117] M. S. Garcia, M. I. Albero, C. Sánchez-Pedreño, and M. S. Abuherba, "Spectrophotometric determination of cimetidine in pharmaceuticals and urine using batch and flow-injection methods," Journal of Pharmaceutical and Biomedical Analysis, vol. 32, no. 4-5, pp. 1003-1010, 2003.

[118] M. S. Garcia, M. I. Albero, C. Sánchez-Pedreño, and M. S. Abuherba, "Spectrophotometric determination of cimetidine in pharmaceuticals and urine using batch and flow-injection methods," Journal of Pharmaceutical and Biomedical Analysis, vol. 32, no. 4-5, pp. 1003-1010, 2003.

[119] K. M. Kelani, A. M. Aziz, M. A. Hegazy, and L. A. Fattah, "Different spectrophotometric methods for the determination of cimetidine, ranitidine hydrochloride, and famotidine," Spectroscopy Letters, vol. 35, no. 4, pp. 543-563, 2002.

[120] T. Imamura, T. Nagata, K. Kuddo, K. Kimura, and M. Noda, "Sensitive detection and determination of cimetidine in human tissues with high-performance liquid chromatography," Journal of Chromatography B, vol. 534, pp. 253-259, 1990.

[121] P. Betto, E. Ciranni-Signoretti, and R. Di Fava, "Determination of cimetidine and related impurities in pharmaceutical formulations by high-performance liquid chromatography," Journal of Chromatography, vol. 586, no. 1, pp. 149-152, 1991.

[122] R. Chiou, R. J. Stubbs, and W. F. Bayne, "Determination of cimetidine in plasma and urine by high-performance liquid chromatography," Journal of Chromatography B, vol. 377, pp. 441-446, 1986.

[123] D. R. P. Guay, H. N. Bockbrader, and G. R. Matzke, "Highperformance liquid chromatographic analysis of cimetidine in serum and urine," Journal of Chromatography, vol. 228, pp. 398403, 1982.

[124] M. G. Kunitani, D. A. Johnson, R. A. Upton, and S. Riegelman, "Convenient and sensitive high-performance liquid chromatography assay for cimetidine in plasma or urine," Journal of Chromatography, vol. 224, no. 1, pp. 156-161, 1981.

[125] V. Nitsche and H. Mascher, Journal of Chromatography, vol. 237, pp. 449-452, 1983.
[126] J. S. Kaka, "Rapid method for cimetidine and ranitidine determination in human and rat plasma by HPLC," Journal of Liquid Chromatography, vol. 11, no. 16, pp. 3447-3456, 1988.

[127] A. M. Rustam, "Estimation of cyclosporin-A in whole blood by simple and rapid reversed-phase HPLC utilizing a salting-out extraction procedure," Journal of Chromatographic Science, vol. 28, no. 11, pp. 594-598, 1990.

[128] A. M. Rustum and N. E. Hoffman, "Liquid chromatographic determination of cimetidine in whole blood and plasma by using short polymeric reverse phase column," Journal of the Association of Official Analytical Chemists, vol. 71, no. 3, pp. 519$522,1988$.

[129] E. G. Lovering and N. M. Curran, "High-performance liquid chromatographic determination of cimetidine and related compounds (raw material and tablets)," Journal of Chromatography, vol. 319, no. 2, pp. 235-240, 1985.

[130] H. A. Strong and M. Spino, "Highly sensitive determination of cimetidine and its metabolites in serum and urine by high-performance liquid chromatography," Journal of Chromatography $B$, vol. 422, pp. 301-308, 1987.

[131] W. C. Randolph, V. L. Osborne, S. S. Walkenstein, and A. P. Intoccia, "High pressure liquid chromatographic analysis of cimetidine, a histamine $\mathrm{H}_{2}$ receptor antagonist, in blood and urine," Journal of Pharmaceutical Sciences, vol. 66, no. 8, pp. 1148-1150, 1977.

[132] G. W. Mihaly, S. Cockbain, D. B. Jones, R. G. Hanson, and R. A. Smallwood, "High-pressure liquid chromatographic determination of cimetidine in plasma and urine," Journal of Pharmaceutical Sciences, vol. 71, no. 5, pp. 590-592, 1982.

[133] J. A. Ziemniak, D. A. Chiarmonte, and J. J. Schentag, "Liquidchromatographic determination of cimetidine, its known metabolites, and creatinine in serum and urine," Clinical Chemistry, vol. 27, no. 2, pp. 272-275, 1981.

[134] Q. Lin, G. L. Lensmeyer, and F. C. Larson, "Quantitation of cimetidine and cimetidine sulfoxide in serum by solidphase extraction and solvent-recycled liquid chromatography," Journal of Analytical Toxicology, vol. 9, no. 4, pp. 161-166, 1985.

[135] B. Lorenzo and D. E. Drayer, "Improved method for the measurement of cimetidine in human serum by reverse-phase highpressure liquid chromatography," Journal of Laboratory and Clinical Medicine, vol. 97, no. 4, pp. 545-550, 1981.

[136] S. J. Soldin, D. R. Fingold, P. C. Fenje, and W. A. Mahon, "High performance liquid chromatographic analysis of cimetidine in serum," Therapeutic Drug Monitoring, vol. 1, no. 3, pp. 371-379, 1979.

[137] M. T. Kelly, D. McGuirk, and F. J. Bloomfield, "Determination of cimetidine inhuman plasma by high-performance liquid chromatography following liquid-liquid extraction," Journal of Chromatography B, vol. 668, no. 1, pp. 117-123, 1995.

[138] K. Xu, V. K. Arora, A. K. Chaudhary, R. B. Cotton, and I. A. Blair, "Quantitative analysis of cimetidine in human plasma using LC/APCI/SRM/MS," Biomedical Chromatography, vol. 13, no. 7, pp. 455-461, 1999.

[139] M. Abdel-Rahim, D. Ezra, C. Peck, and J. Lazar, "Liquid-chromatographic assay of cimetidine in plasma and gastric fluid," Clinical Chemistry, vol. 31, no. 4, pp. 621-623, 1985.

[140] J. Hempenius, J. Wieling, J. P. G. Brakenhoff, F. A. Maris, and J. H. G. Jonkman, "High-throughput solid-phase extraction for the determination of cimetidine in human plasma," Journal of Chromatography B, vol. 714, no. 2, pp. 361-368, 1998. 
[141] G. W. Mihaly, S. Cockbain, D. B. Jones, R. G. Hanson, and R. A. Smallwood, "High-pressure liquid chromatographic determination of cimetidine in plasma and urine," Journal of Pharmaceutical Sciences, vol. 71, no. 5, pp. 590-592, 1982.

[142] W. C. Randolph, R. C. Heel, T. M. Speight, and G. S. Avery, "High-pressure liquid chromatographie analysis of cimetidine, a histamine $\mathrm{H}_{2}$-receptor antagonist, in blood and urine," Journal of Pharmaceutical Sciences, vol. 66, no. 8, pp. 1148-1150, 1977.

[143] N. E. Larsen, P. Hesselfeldt, S. J. Rune, and E. F. Havidberg, "Cimetidine assay in human plasma by liquid chromatography," Journal of Chromatography B, vol. 163, no. 1, pp. 57-63, 1979.

[144] M. Kozma and L. Vereczkey, "Rapid method for determination of cimetidine in biological fluids by high-performance liquid chromatography using extrelut extraction," Journal of Chromatography B, vol. 273, no. 1, pp. 223-227, 1983.

[145] E. Jantratid, S. Prakongpan, J. P. Foley, J. B. Dressman, and J. B. Dressman, "Convenient and rapid determination of cimetidine in human plasma using perchloric acid-mediated plasma protein precipitation and high-performance liquid chromatography," Biomedical Chromatography, vol. 21, no. 9, pp. 949-957, 2007.

[146] T. Iqbal, C. S. Karyekar, M. Kinjo, G. C. Ngan, and T. C. Dowling, "Validation of a simplified method for determination of cimetidine in human plasma and urine by liquid chromatography with ultraviolet detection," Journal of Chromatography B, vol. 799, no. 2, pp. 337-341, 2004.

[147] J. A. Apffel, U. A. Th. Brinkman, R. W. Frei et al., "Analysis of cimetidine in biological fluids by high performance liquid chromatography," Journal of Liquid Chromatography and Related Technologies, vol. 5, no. 12, pp. 2413-2422, 1982.

[148] L. Dong-Sun, K. Kyung-Hee, and S. Hee-Soo, "Determination of cimetidine in human urine by column switching HPLC with UV-detection," Bulletin of the Korean Society, vol. 16, no. 2, pp. 77-196, 1995.

[149] Y. Gomita, M. Nanba, K. Furono, K. Eto, and Y. Araki, "Microdetermination of cimetidine in rat plasma by high-performance liquid chromatography," International Journal of Pharmaceutics, vol. 54, no. 2, pp. 89-93, 1989.

[150] S. Pillai and I. Singhvi, "Spectrophotometric simultaneous estimation of ranitidine hydrochloride and ondansetron hydrochloride from tablet formulation," Indian Journal of Pharmaceutical Sciences, vol. 69, no. 4, pp. 601-604, 2007.

[151] E. M. Hassan and F. Belal, "Kinetic spectrophotometric determination of nizatidine and ranitidine in pharmaceutical preparations," Journal of Pharmaceutical and Biomedical Analysis, vol. 27, no. 1-2, pp. 31-38, 2002.

[152] M. I. Walash, F. Belal, F. Ibrahim, M. Hefnawy, and M. Eid, "Kinetic spectrophotometric method for the determination of ranitidine and nizatidine in pharmaceuticals," Journal of AOAC International, vol. 85, no. 6, pp. 1316-1323, 2002.

[153] D. Dumanović, I. Juranić, D. Dzeletović, V. M. Vasić, and J. Jovanović, "Protolytic constants of nizatidine, ranitidine and $\mathrm{N}, \mathrm{N}^{\prime}$-dimethyl-2-nitro-1,1-ethenediamine; spectrophotometric and theoretical investigation," Journal of Pharmaceutical and Biomedical Analysis, vol. 15, no. 11, pp. 1667-1678, 1997.

[154] K. Basavaiah and P. Nagegowda, "Determination of ranitidine hydrochloride in pharmaceutical preparations by titrimetry and visible spectrophotometry using bromate and acid dyes," Farmaco, vol. 59, no. 2, pp. 147-153, 2004.

[155] M. Walash, M. Sharaf-El Din, M. E.-S. Metwalli, and M. RedaShabana, "Spectrophotometric determination of nizatidine and ranitidine through charge transfer complex formation," Archives of Pharmacal Research, vol. 27, no. 7, pp. 720-726, 2004.

[156] S. Al-Ghannam and F. Belal, "Spectrophotometric determination of three anti-ulcer drugs through charge-transfer complexation," Journal of AOAC International, vol. 85, no. 5, pp. 10031008, 2002.

[157] A. M. Rustum, A. Rahman, and N. E. Hoffman, "High-performance liquid chromatographic determination of ranitidine in whole blood and plasma by using a short polymeric column," Journal of Chromatography B, vol. 421, no. 2, pp. 418-424, 1987.

[158] G. W. Mihaly, O. H. Drummer, A. Marshall, R. A. Smallwood, and W. J. Louis, "High-pressure liquid chromatographic determination of ranitidine, a new $\mathrm{H}_{2}$-receptor antagonist, in plasma and urine," Journal of Pharmaceutical Sciences, vol. 69, no. 8, pp. 1155-1157, 1980.

[159] A. M. Rustum, A. Rahman, and N. E. Hoffman, "High-performance liquid chromatographic determination of ranitidine in whole blood and plasma by using a short polymeric column," Journal of Chromatography B, vol. 421, no. 2, pp. 418-424, 1987.

[160] A. Ahmadiani and H. Amini, "Rapid determination of ranitidine in human plasma by high-performance liquid chromatography without solvent extraction," Journal of Chromatography B, vol. 751, no. 2, pp. 291-296, 2001.

[161] G. Mullersman and H. Derendorf, "Rapid analysis of ranitidine in biological fluids and determination of its erythrocyte partitioning," Journal of Chromatography B, vol. 381, no. 2, pp. 385391, 1986.

[162] C. F. Wong, K. K. Peh, and K. H. Yuen, "Simple high-performance liquid chromatographic method for the determination of ranitidine in human plasma," Journal of Chromatography B, vol. 718, no. 1, pp. 205-210, 1998.

[163] P. F. Carey, L. E. Martin, and P. E. Owen, "Determination of ranitidine and its metabolites in human urine by reversed-phase ion-pair high-performance liquid chromatography," Journal of Chromatography B, vol. 225, no. 1, pp. 161-168, 1981.

[164] T. Prueksaritanont, N. Sittichai, S. Prueksaritanont, and R. Vongsaroj, "Simultaneous determination of ranitidine and its metabolites in human plasma and urine by high-performance liquid chromatography," Journal of Chromatography B, vol. 490, no. 1, pp. 175-185, 1989.

[165] D. Farthing, K. L. R. Brouwer, I. Fakhry, and D. Sica, "Solidphase extraction and determination of ranitidine in human plasma by a high-performance liquid chromatographic method utilizing midbore chromatography," Journal of Chromatography $B$, vol. 688 , no. 2, pp. 350-353, 1997.

[166] T. L. Lloyd, T. B. Perschy, A. E. Gooding, and J. J. Tomlinson, "Robotic solid phase extraction and high performance liquid chromatographic analysis of ranitidine in serum or plasma," Biomedical Chromatography, vol. 6, no. 6, pp. 311-316, 1992.

[167] H. T. Karnes, K. Opong-Mensah, D. Farthing, and L. A. Beightol, "Automated solid-phase extraction and high-performance liquid chromatographic determination of ranitidine from urine, plasma and peritoneal dialysate," Journal of Chromatography B, vol. 422, pp. 165-173, 1987.

[168] C. F. Wong, K. K. Peh, and K. H. Yuen, "Simple high-performance liquid chromatographic method for the determination of ranitidine in human plasma," Journal of Chromatography B, vol. 718, no. 1, pp. 205-210, 1998.

[169] C. López-Calull, L. García-Capdevila, C. Arroyo, and J. Bonal, "Simple and robust high-performance liquid chromatographic method for the determination of ranitidine in microvolumes of 
human serum," Journal of Chromatography B, vol. 693, no. 1, pp. 228-232, 1997.

[170] M. S. Salem, A. M. Gharaiebeh, H. N. Alkaysi, and A. Badwan, "High-performance liquid chromatographic analysis of ranitidine in plasma and urine," Journal of Clinical Pharmacy and Therapeutics, vol. 13, no. 5, pp. 351-357, 1988.

[171] D. Farthing, K. L. R. Brouwer, I. Fakhry, and D. Sica, "Solidphase extraction and determination of ranitidine in human plasma by a high-performance liquid chromatographic method utilizing midbore chromatography," Journal of Chromatography $B$, vol. 688, no. 2, pp. 350-353, 1997.

[172] T. Prueksaritanont, N. Sittichai, S. Prueksaritanont, and R. Vongsaroj, "Simultaneous determination of ranitidine and its metabolites in human plasma and urine by high-performance liquid chromatography," Journal of Chromatography B, vol. 490, no. 1, pp. 175-185, 1989.

[173] A. Rahman, N. E. Hoffman, and A. M. Rustum, "Determination of ranitidine in plasma by high-performance liquid chromatography," Journal of Pharmaceutical and Biomedical Analysis, vol. 7, no. 6, pp. 747-753, 1989.

[174] P. Viñas, N. Campillo, C. López-Erroz, and M. HernándezCórdoba, "Use of post-column fluorescence derivatization to develop a liquid chromatographic assay for ranitidine and its metabolites in biological fluids," Journal of Chromatography B, vol. 693, no. 2, pp. 443-449, 1997.

[175] M. S. Lant, L. E. Martin, and J. Oxford, "Qualitative and quantitative analysis of ranitidine and its metabolites by high-performance liquid chromatography-mass spectrometry," Journal of Chromatography, vol. 323, no. 1, pp. 143-152, 1985.

[176] M. X. Kokoletsi, S. Kafkala, and M. Tsiaganis, "A novel gradient HPLC method for simultaneous determination of ranitidine, methylparaben and propylparaben in oral liquid pharmaceutical formulation," Journal of Pharmaceutical and Biomedical Analysis, vol. 38, no. 4, pp. 763-767, 2005.

[177] A. S. Amin, S. A. Shama, I. S. Ahmed, and E. A. Gouda, "Spectrophotometric determination of famotidine through oxidation with N-bromosuccinimide and cerric sulphate," Analytical Letters, vol. 35, no. 11, pp. 1851-1862, 2002.

[178] P. D. Tzanavaras, A. Verdoukas, and T. Balloma, “Optimization and validation of a dissolution test for famotidine tablets using flow injection analysis," Journal of Pharmaceutical and Biomedical Analysis, vol. 41, no. 2, pp. 437-441, 2006.

[179] A. K. S. Ahmad, M. A. Kawy, and M. Nebsen, "Spectrophotometric and spectrofluorimetric determination of famotidine and ranitidine using 1,4-benzoquinone reagent," Analytical Letters, vol. 32, no. 7, pp. 1403-1419, 1999.

[180] Y. K. Agrawal, K. Shivramchandra, G. N. Singh, and B. E. Rao, "Spectrophotometric determination of famotidine in pharmaceutical preparations," Journal of Pharmaceutical and Biomedical Analysis, vol. 10, no. 7, pp. 521-523, 1992.

[181] N. Rahman and M. Kashif, "Application of ninhydrin to spectrophotometric determination of famotidine in drug formulations," Farmaco, vol. 58, no. 10, pp. 1045-1050, 2003.

[182] H. A. Mohamad, "Spectrophotometric determination of famotidine using p-chloranilic acid," Bulletin of Pharmaceutical Sciences (Assiut University), vol. 23, no. 223, pp. 157-163, 2000.

[183] B. V. Kamath, K. Shivram, and S. Vangani, "Spectrophotometry determination of famotidine by charge transfer complexation," Analytical Letters, vol. 25, no. 12, pp. 2239-2247, 1992.

[184] El-Yazbi and A. Fawzy, "Second-derivative spectrophotometric determination of famotidine," Spectroscopy Letters, vol. 25, no. 7, pp. 1011-1021, 1992.
[185] A. Z. Abu Zuhri, R. M. Shubietah, and G. M. Badah, "Extractional-spectrophotometric determination of famotidine in pharmaceutical formulations," Journal of Pharmaceutical and Biomedical Analysis, vol. 21, no. 2, pp. 459-465, 1999.

[186] S. M. Blaih, F. A. El-Yazbi, and E. M. Hassan, "Spectrophotometric and titrimetric methods for the determination of famotidine in dosage form," S.T.P. Pharma Sciences, vol. 4, no. 6, pp. 492494, 1994.

[187] S. Raghuveer, C. M. R. Srivastava, and D. K. Vatsa, "Spectrophotometric determination of famotidine in its dosage forms," Indian Drugs, vol. 29, no. 7, pp. 320-322, 1992.

[188] H. Maurer, "Chromatography of histamine $\mathrm{H}_{1}$ - and $\mathrm{H}_{2}$-receptor blockers in biosamples," Journal of Chromatography B, vol. 531, pp. 369-405, 1990.

[189] B. Carkir, A. Tosun, and M. Sahin, Journal of Pharmaceutical Sciences, vol. 3, pp. 493-496, 1997.

[190] M. Campanero, I. Bueno, M. Arangoa et al., "Improved selectivity in detection of polar basic drugs by liquid chromatographyelectrospray ionization mass spectrometry: illustration using an assay method for the determination of famotidine in human plasma," Journal of Chromatography B, vol. 763, no. 1-2, pp. 2133, 2001.

[191] T. C. Dowling and R. F. Frye, "Determination of famotidine in human plasma and urine by high-performance liquid chromatography," Journal of Chromatography B, vol. 732, no. 1, pp. 239-243, 1999.

[192] A. Zoest, S. Wanwimoluk, and C. Hung, "Sensitive highperformance liquid chromatographic determination of famotidine in plasma: application to pharmacokinetic study," Journal of Chromatography B, vol. 572, no. 1-2, pp. 227-238, 1991.

[193] S. Singh, S. Kumar, N. Sharda, and A. K. Chakraborti, "New findings on degradation of famotidine under basic conditions: Identification of a hitherto unknown degradation product and the condition for obtaining the propionamide intermediate in pure form," Journal of Pharmaceutical Sciences, vol. 91, no. 1, pp. 253-257, 2002.

[194] Z. Deĝim and I. Aĝabeyoĝlu, "Nonisothermal stability tests of famotidine and nizatidine," Il Farmaco, vol. 729, no. 9, pp. 729$735,2002$.

[195] M. S. Suleiman, H. Y. Muti, M. E. Abdel-Hamid, M. Hassan, Y. M. El-Sayed, and N. M. Najib, "A stability-indicating HPLC analysis of famotidine and its application to kinetic studies," Analytical Letters, vol. 22, no. 6, pp. 1499-1512, 1989.

[196] G. Junnarkar and S. Stavchansky, "Thermal degradation of famotidine in aqueous solution stability indicating assay," Analytical Letters, vol. 25, no. 10, pp. 1907-1913, 1992.

[197] S. E. Biffar and D. J. Mazzo, "Reversed-phase determination of famotidine, potential degradates, and preservatives in pharmaceutical formulations by high-performance liquid chromatography using silica as a stationary phase," Journal of Chromatography $A$, vol. 363, no. 2, pp. 243-249, 1986.

[198] S. Husain, S. Khalid, V. Nagaraju, and N. R. Rao, "High-performance liquid chromatographic separation and determination of small amounts of process impurities of famotidine in bulk drugs and formulations," Journal of Chromatography A, vol. 743, no. 2, pp. 328-334, 1996.

[199] X.-Z. Qin, D. P. Ip, K. H.-C. Chang, P. M. Dradransky, M. A. Brooks, and T. Sakuma, "Pharmaceutical application of LCMS. 1-characterization of a famotidine degradates in a package screening study by LC-APCI MS," Journal of Pharmaceutical and Biomedical Analysis, vol. 12, no. 2, pp. 221-233, 1994. 
[200] W. C. Vincek, M. L. Constanzer, G. A. Hessey II, and W. F. Bayne, "Analytical method for the quantification of famotidine, an $\mathrm{H}_{2}$-receptor blocker, in plasma and urine," Journal of Chromatography B, vol. 338, pp. 438-443, 1985.

[201] L. Cvitkovič, L. Zupančič-Kralj, and J. Marsel, "Determination of famotidine in human plasma and urine by high-performance liquid chromatography," Journal of Pharmaceutical and Biomedical Analysis, vol. 9, no. 2, pp. 207-210, 1991.

[202] S. Wanwimolruk, A. R. Zoest, S. Z. Wanwimolruk, and C. T. Hung, "Sensitive high-performance liquid chromatographic determination of famotidine in plasma. Application to pharmacokinetic study," Journal of Chromatography B, vol. 572, no. 1-2, pp. 227-238, 1991.

[203] Y. Imai and S.-I. Kobayashi, "A simple method for the quantification of famotidine in human plasma and urine by paired-ion high performance liquid chromatography," Biomedical Chromatography, vol. 6, no. 5, pp. 222-223, 1992.

[204] P. Guo, L. M. Ye, B. Lu, Y. J. He, and Z. W. Li, "Direct injection of plasma to determine famotidine in plasma using HPLC column switching technique," Acta Pharmaceutica Sinica, vol. 25, no. 8, pp. 622-625, 1990.

[205] L. Zhong and K. C. Yeh, "Determination of famotidine in human plasma by high performance liquid chromatography with column switching," Journal of Pharmaceutical and Biomedical Analysis, vol. 16, no. 6, pp. 1051-1057, 1998.

[206] N. Helali, F. Darghouth, and L. Monser, "RP-HPLC determination of famotidine and its potential impurities in pharmaceuticals," Chromatographia, vol. 60, no. 7-8, pp. 455-460, 2004.

[207] G. Carlucci, P. Mazzeo, C. Vetuschi, and E. Di Giuseppe, "Reversed-phase high-performance liquid chromatographic and derivative UV spectrophotometric determination of famotidine in pharmaceutical preparations," International Journal of Pharmaceutics, vol. 102, no. 1-3, pp. 271-274, 1994.

[208] A. Zarghi, A. Shafaati, S. M. Foroutan, and A. Khoddam, "Development of a rapid HPLC method for determination of famotidine in human plasma using a monolithic column," Journal of Pharmaceutical and Biomedical Analysis, vol. 39, no. 3-4, pp. 677-680, 2005.

[209] B. V. Kamath, K. Shivram, B. L. Newalkar, and A. C. Shah, "Liquid chromatographic analysis and degradation kinetics of famotidine," Journal of Liquid Chromatography \& Related Technologies, vol. 16, no. 5, pp. 1007-1014, 1993.

[210] N. Helali and L. Monser, "Stability indicating method for famotidine in pharmaceuticals using porous graphitic carbon column," Journal of Separation Science, vol. 31, no. 2, pp. 276-282, 2008.

[211] N. Sultana, M. S. Arayne, S. Shamim, and A. Naz, "Validated method for the simultaneous determination of gemifloxacin and $\mathrm{H}_{2}$-receptor antagonists in bulk, pharmaceutical formulations and human serum by RP-HPLC; in-vitro applications," Journal of the Chinese Chemical Society, vol. 58, no. 5, pp. 629636, 2011.

[212] S. Naveed, N. Sultana, M. S. Arayne et al., "Simultaneous determination of lisinopril and $\mathrm{H}_{2}$ antagonists in API, formulations and human serum by using two different HPLC systems," Medicinal Chemistry Research, vol. 21, no. 12, pp. 4037-4042, 2012.

[213] N. Sultan, S. Naveed, and M. S. Arayne, "RP-HPLC method for the simultaneous determination of captopril and $\mathrm{H}_{2}$-receptor antagonist: application to interaction studies," Medicinal Chemistry, vol. 3, no. 1, pp. 183-187, 2013.
[214] M. S. Arayne, N. Sultana, M. H. Zuberi, and F. A. Siddiqui, "Simultaneous determination of metformin, cimetidine, famotidine, and ranitidine in human serum and dosage formulations using HPLC with UV detection," Journal of Chromatographic Science, vol. 48, no. 9, pp. 721-725, 2010.

[215] S. Najma, M. S. Arayne, S. Naz et al., "Simultaneous determination of prazosin and $\mathrm{H}_{2}$ receptor antagonists from bulk materials, pharmaceutical formulations and human serum by RPHPLC," Inventi Impact, vol. 2010, article Inventi:paqa/37/10, 2010.

[216] N. Sultana, M. Saeed Arayne, S. Gul, M. Akhtar, and S. Shamim, "Simultaneous determination of sparfloxacin and commonly used $\mathrm{H}_{2}$ receptor antagonists by RP-HPLC: application to in vitro drug interactions," Medicinal Chemistry Research, vol. 21, no. 7, pp. 974-982, 2012.

[217] C. HO, H.-M. Huang, S.-Y. Hsu, C.-Y. Shaw, and B.-L. Chang, "Simultaneous high-performance liquid chromatographic analysis for famotidine, ranitidine $\mathrm{HCl}$, cimetidine, and nizatidine in commercial products," Drug Development and Industrial Pharmacy, vol. 25, no. 3, pp. 379-385, 1999.

[218] D. Zendelovska and T. Stafilov, "Development of an HPLC method for the determination of ranitidine and cimetidine in human plasma following SPE," Journal of Pharmaceutical and Biomedical Analysis, vol. 33, no. 2, pp. 165-173, 2003. 

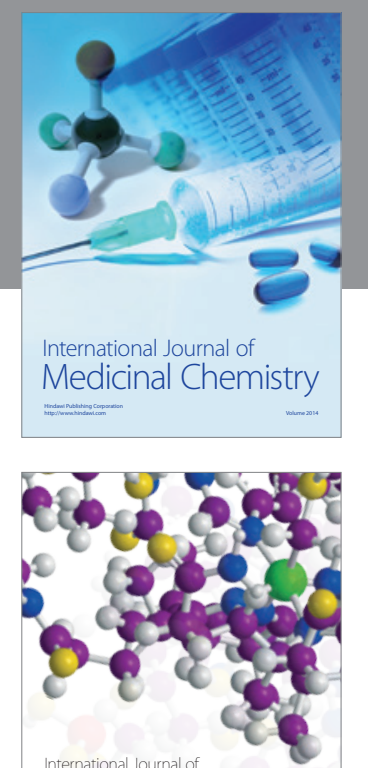

\section{Carbohydrate} Chemistry

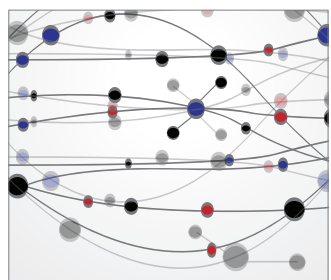

The Scientific World Journal
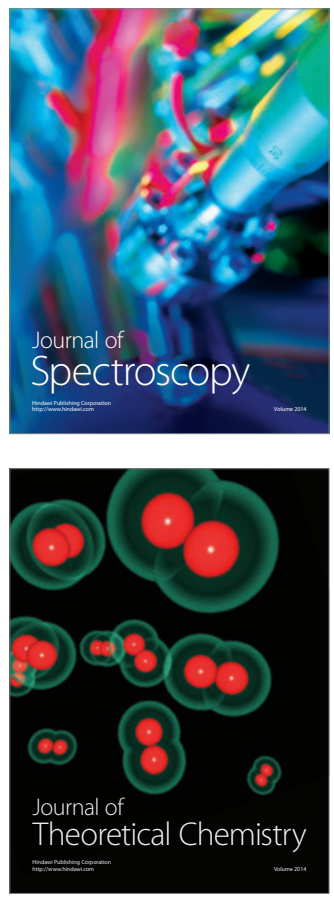
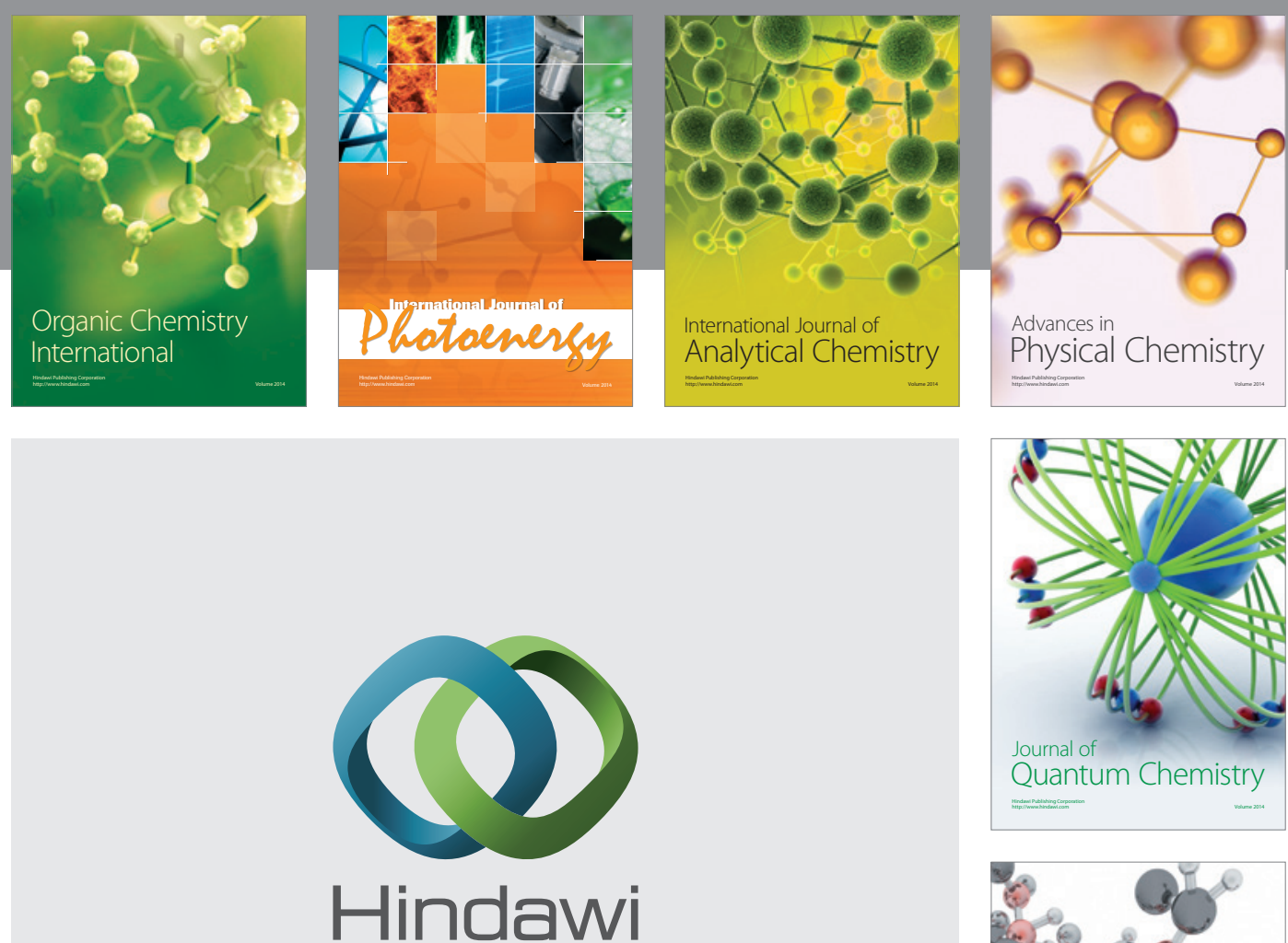

Submit your manuscripts at

http://www.hindawi.com

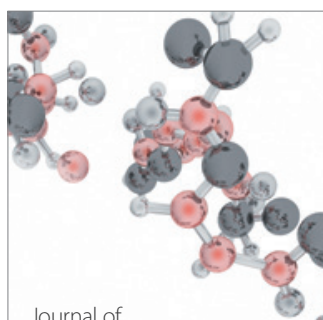

Analytical Methods

in Chemistry

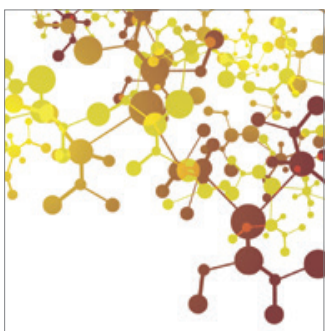

Journal of

Applied Chemistry

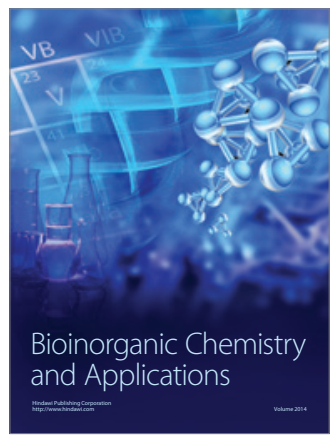

Inorganic Chemistry
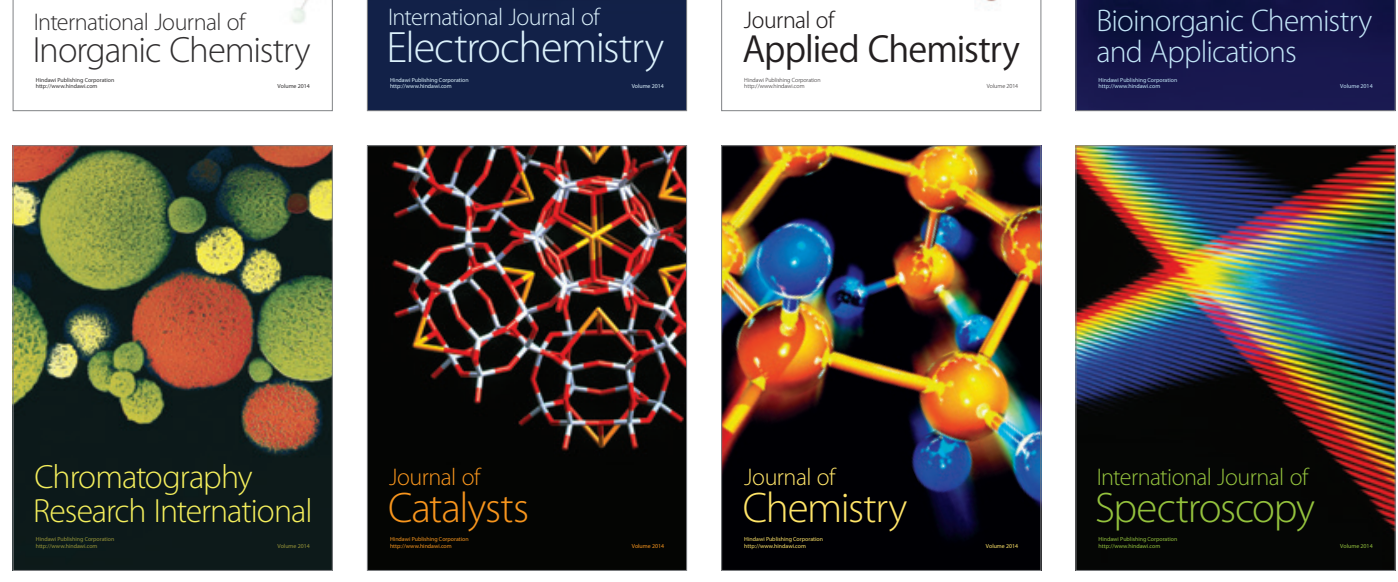